\title{
Optimal Pricing for Services of Iran's Internet Exchange Points: A Fuzzy Geometric Programming Approach
}

\author{
Akbar Ahmadi ${ }^{1}$ \\ a.ahmadi@atu.ac.ir
}

Received: 26/01/2021 | Accepted: 01/08/2021

\begin{abstract}
The optimal pricing of goods and services is one of the most challenging issues in economics. Scarcity of resources which causes a good or a service priced more expensive, on the one hand, and its costs of production on the other, motivate researchers to find optimum price. This paper investigates an optimal pricing scheme for Iran's IXPs services including $1 \mathrm{Ge}$ ports, 10GE, and 100GE ports through a Fuzzy Geometric Programming model. "Internet exchange points" (IXPS) are infrastructures through which Autonomous Systems (AS) such as Internet Service Providers (ISPs), Content Delivery Networks (CDNs), Content Providers (CPs), and other internet networks, peer with each other to exchange internet traffic more efficiently. These points provide their members with a wide variety of services. How should these services be priced so that the maximum number of potential members can be connected to IXP and also the profit of IXP is maximized? The FGP model answers these questions. According to the results of this paper, the demand for the services of IXPs is a function of the price of ports and the number of services provided in each IXP. This demand function is normal; i.e., the quantity demanded has a negative relationship with the port price and a positive relationship with the number of services. The demand function for $1 \mathrm{GE}$ ports is price inelastic, while the elasticities of the price for 10GE and 100GE is greater than 1. Also, it has been shown that the optimal price of the Iranian IXP services based on the FGP model proposes a higher price of $10.3 \%$ compared to its current price, and a lower price for 10GE and 100GE ports of $1.75 \%$ and $14.5 \%$ respectively compared to the current price. The sensitivity analysis shows that the changes of price elasticity up to $90 \%$, have no impact on the profit of IXP, but it has a small effect on the optimum price.
\end{abstract}

Keywords: Internet Pricing, Internet Exchange Points, Demand for IXP, Mathematical Optimization, Fuzzy Geometric Programming.

JEL Classification: C02, D42, D22, D24.

1. Faculty Member of Economics, Researches Institute, Allameh Tabatabae'i University, Tehran, Iran. 


\section{قيمتَذارى بهينة خدمات مراكز تبادل تر افيكى

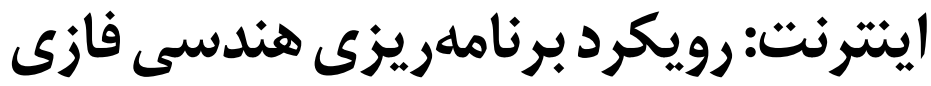

a.ahmadi@atu.ac.ir

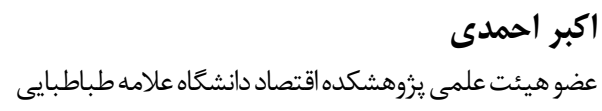

\section{مقاله يثزوشى}

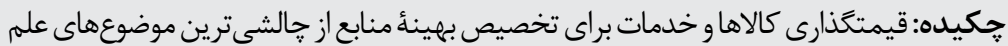

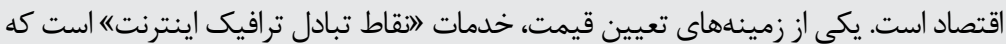

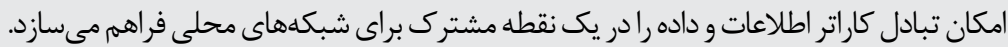

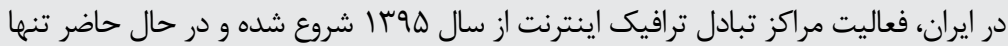

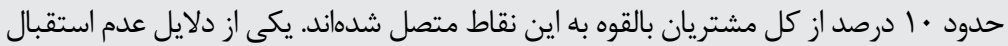

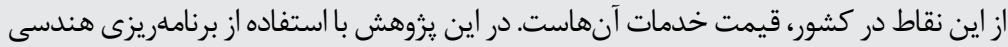

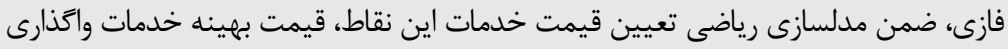

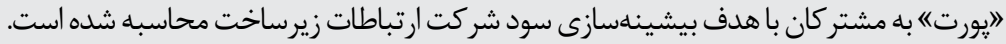

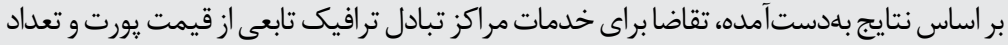

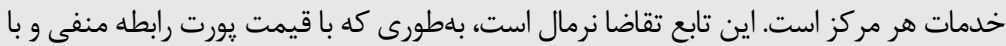

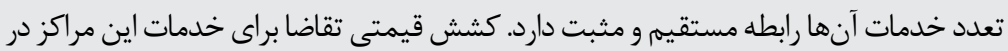

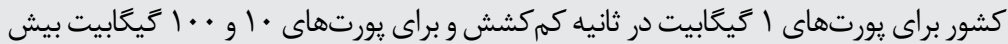

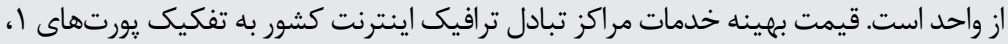

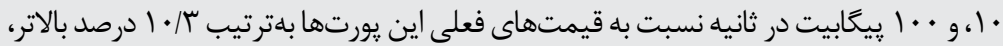

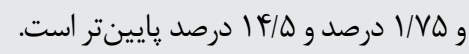

كليدوازهها: قيمتگذارى، نقاط تبادل ترافيك اينترنت، تقاضاى خدمات IXP، بهينهيابى رياضى، برنامهريزى هندسى فازى طبقهبندى C02, D42, D22, D24:JEL. 


\section{dola}

تعيين قيمت بهينه براى كالاها و خدماتى كه توليد و مصرف آنها در شرايط بازار رقابت كامل

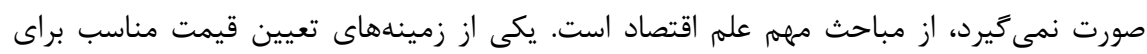

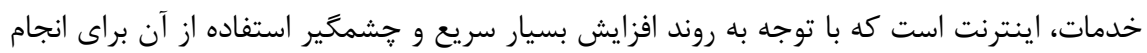

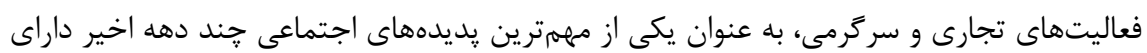

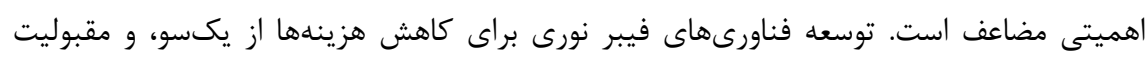

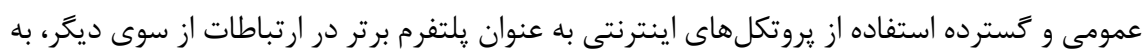

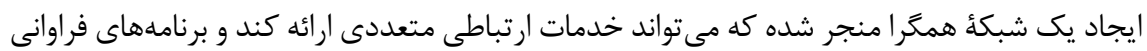

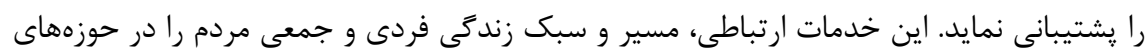

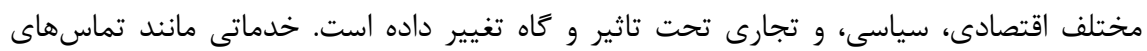
صوتى و تصويرى، ارسال و دريافت عكس و متن به صورت برخط، و انواع بازىها و سركرمى نهى نهاى

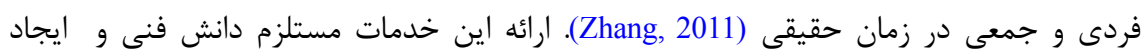
زيرساختهايى است كه علاوه بر هزينهبر بودن، ظرفيت محدودى براى استفاده دارند. تامين كنندكان

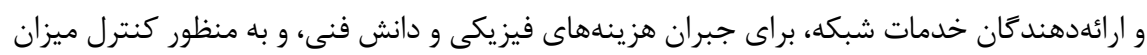

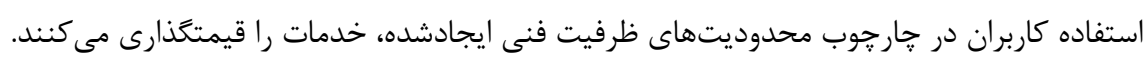

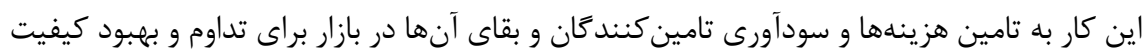

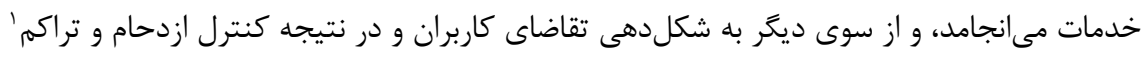

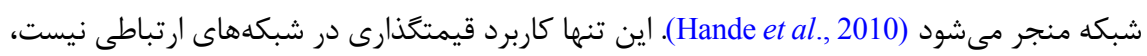
بلكه با شناخت بيشتر از ويزگى ها و خدمات شبكه مىتوان نقشهاى ديكرى نيز براى قيمتخذارى

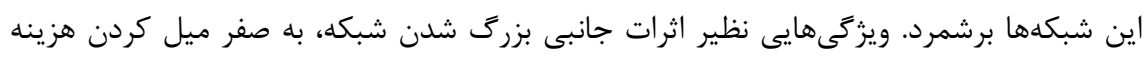

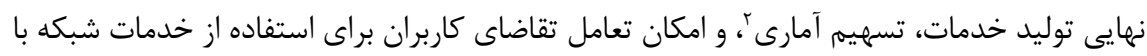
تامين كنند كان اين خدمات (Courcoubetis \& Weber, 2003).

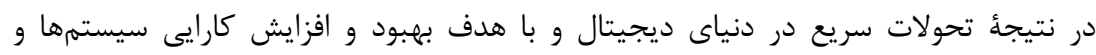
شبكههاى اطلاعاتى، ظهور فناورىهاى جديدى شكل گرفتهاند كه تعيين قيمت منصفانه و بهينه

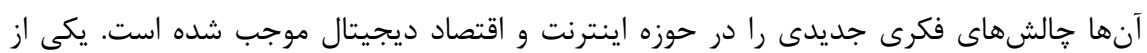


فناورىهاى بلهنسبت جديد كه به منظور كاهش هزينههاى انتقال داده و نيز افزايش كارايى آن از

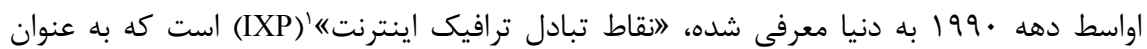
بخشى از زيرساخت ارتباطات اينترنتى كمك شايانى به افزايش كارايى و سرعت انتقال دادهها كرده

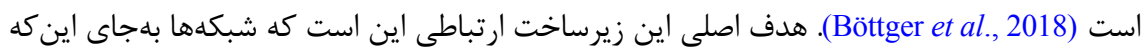

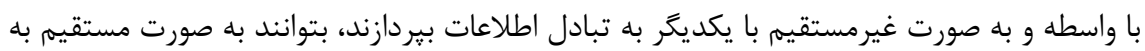
هم متصل شوند تا هم از ايجاد هزينههاى بيشتر جلوكيرى كنند و هم با سرعت بيشترى به تبادل

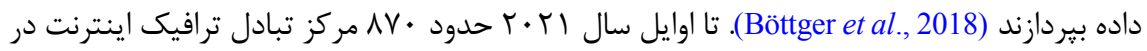
سراسر جهان ايجاد شده است (www.peeringdb.com). با وجود نوظهور بودن نقاط تبادل ترافيك اينترنت، به دليل تاثيراتى كه بر كاهش هزينههاى ترانزيت و افزايش كارايى و سرعت انتقال دادهها داشته، در طى مدت كوتاهى رشد بلنسبت قابلتوجهى

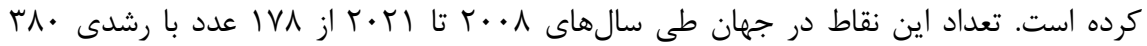

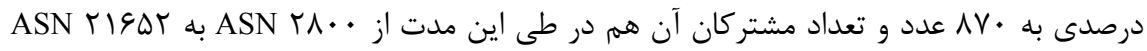

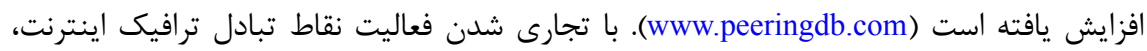
موضوع تامين هزينههاى سرمايهاى و زيرساختى جاى خود را به بيشينهسازى درآمد و سود از طريق تعيين قيمت خدمات داد (Muttitanon \& Samanchuen, 2020). الكَوهاى مختلفى براى تعيين قيمت خدمات اينترنت مورد استفاده قرار گرفته كه مىتوان به الكَى قيمتگذارى ايستا با نرخ يكنواخت (Shakkottai et al., 2008)، قيمتگذارى بر مبناى ميزان استفاده

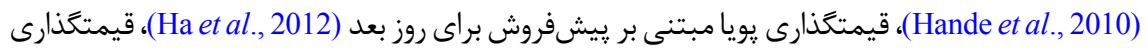

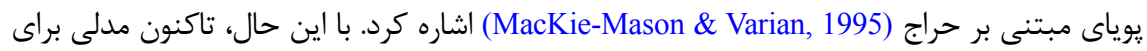
تعيين قيمت بهينه خدمات نقاط تبادل ترافيك اينترنت بر مبناى الكوهاى بهينهايابى رياضى ارائه نشده و

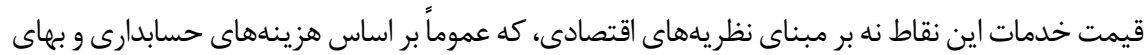
تمامشده خدمات و به صورت ايستا انجام گرفته است (Sen et al., 2013). قيمت خدمات اين مراكز در ايران توسط كميسيون تنظيمم مقررات ارتباطات و بدون مبناى دقيقى

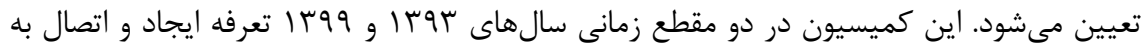
نقاط تبادل ترافيك داده كشور را براى مشتر كان اين نقاط به شرح جدول (1) تصويب كرده است. 
جدول ا: تعرفه ايجاد و اتصال به نقاط تبادل ترافيك داده كشور

\begin{tabular}{|c|c|c|c|c|}
\hline \multicolumn{2}{|c|}{ سال 99 ו } & \multicolumn{2}{|c|}{ سال سوץו } & \multirow[b]{2}{*}{ نوع يورت } \\
\hline در هزينه اتصال اوليه فيال فقطام راهاندازى يكار & 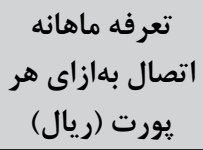 & 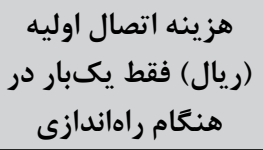 & 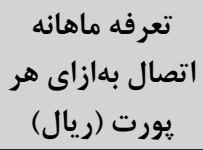 & \\
\hline \multirow{4}{*}{$r \cdot / \cdots / \cdots$} & $1 \cdot / \cdots / \cdots$ & $91 \ldots 1 \ldots$ & $r \cdot / \cdots / \cdots$ & $1 \mathrm{Gbps}$ \\
\hline & $k \cdot / \cdots / \cdots$ & rN/Q $\cdots / \cdots$ & $৭ \Delta / \cdots / \cdots$ & $10 \mathrm{Gbps}$ \\
\hline & $|r \cdot| \cdots / \cdots$ & - & - & 40Gbps \\
\hline & $r \Delta \cdot / \ldots / \ldots$ & - & - & $100 \mathrm{Gbps}$ \\
\hline
\end{tabular}

منبع: صورتجلسات شماره Fl و • اM كميسيون تنظيم مقررات ارتباطات

تعرفههاى فوق به صورت يكنواخت و بدون تغيير نسبت به ميزان تقاضا يا ميزان مصرف مشتركان

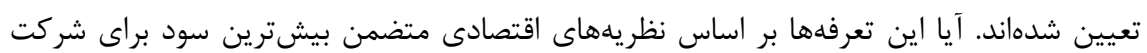
ارتباطات زيرساخت است؟ به نظر مىرسد اين تعرفهها با توجه به ساختار مالكيت و نحوه اداره

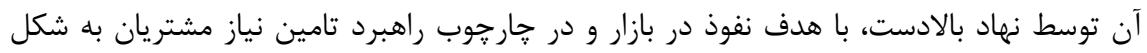

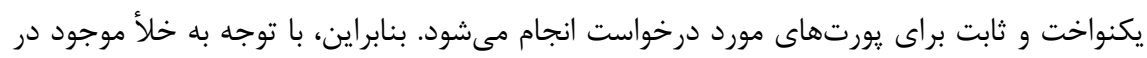

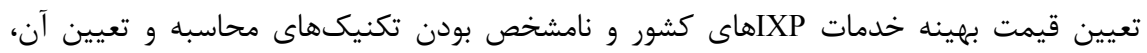
اين يزوهش ضمن معرفى نقاط تبادل ترافيك اينترنت، و خدمات و اهميت آنها در فضاى اقتصاد

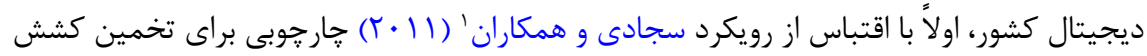

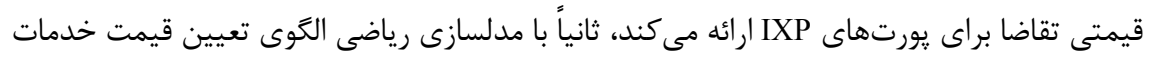

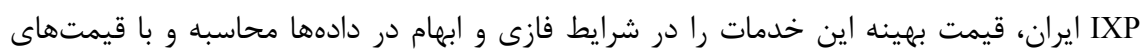
ابلاغى مقايسه مى كند.

\section{معرفى نقاط تبادل ترافيك اينترنت}

نقاط تبادل ترافيك اينترنت يا IXPا بهطور ساده مكانهاى فيزيكى با تجهيزات خاصى نظير

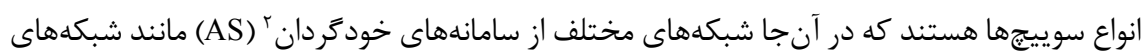

1. Sadjadi et al.

2. Autonomous System 
توليد كننده محتواى اينترنت، شبكههاى مختلف مخابراتى، ارائهدهندكان خدمات اينترنتى، دانشعاهها

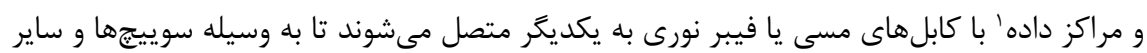
امكانات شبكهاى و فنى موجود در IXP به تبادل ترافيك اينترتى با يكديگر بيردازند. در حقيقت،

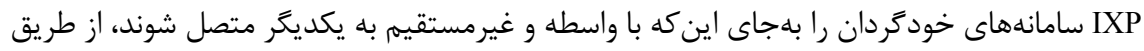

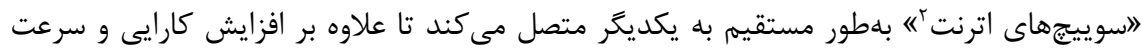
انتقال دادهها، موجب كاهش هزينههاى ذىنفعان شبكه اينترنت را هم فراهم سازد (شكل (1).

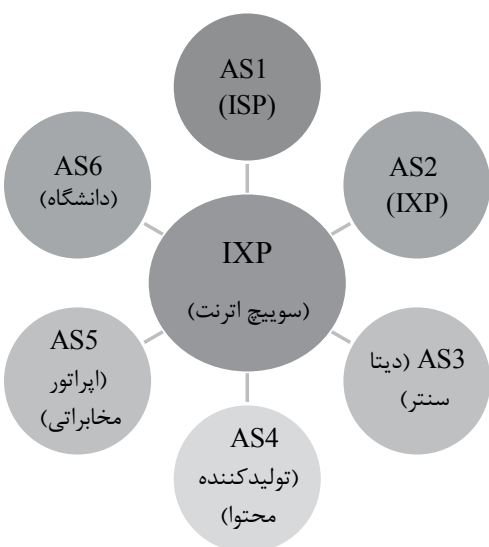

شكل ا: نمونهاى از اتصالات سامانههاى خود كردان به إنهان

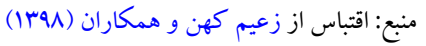

سوييج اترنت وظيفه ارسال، يردازش، و انتقال داده را بين دستخاههاى موجود روى يك شبكه كامِيوترى

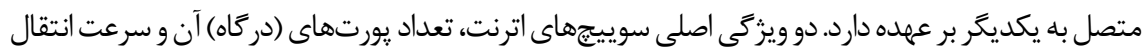
داده است. يورت امكانى است كه براى رد و بدل كردن اطلاعات بين دو كامييوتر استفاده مىشود و به دو

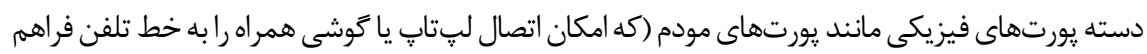

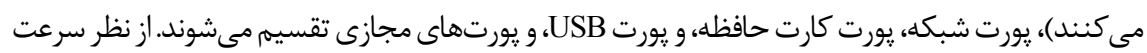




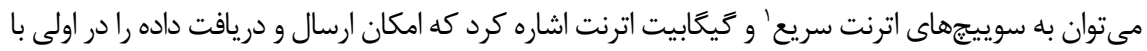

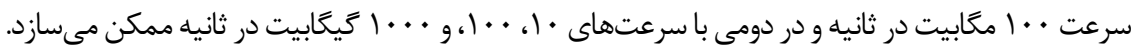
براى درك بهترى از عملكرد 》نقاط تبادل ترافيك اينترنته لازم است بهطور خلاصه به خاستخاه آن اشاره شود. شبكه جهانى اينترنت شبكهاى از سامانههاى خودگردان يا خودكار (AS) است كه در جارجوب قواعد و نظم خاصى كه يروتكل اينترنت ناميده مىشود، امكان ارتباط بين اين سامانهها و نقل و انتقال داده و اطلاعات و محتوا را فراهم مىسازد. سامانههاى خودكردان كه مشتريان بالقوه نقاط

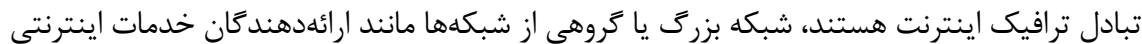
(ISP)، خدمات ابرى، ارائهدهندكان خدمات ارتباط صوتى و تصويرى از راه دور، شبكههاى توزيع محتوا

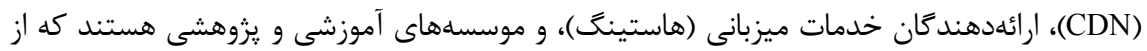
خطمشى و سياست مسيريابى واحدى تبعيت مى كنند و تحت يك مديريت واحد اداره مىشوند. هر

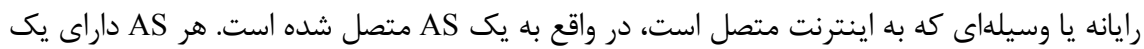

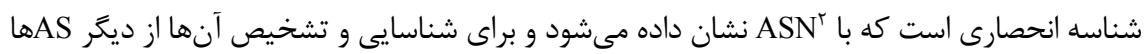

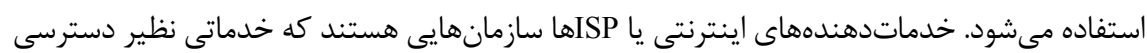
به اينترنت، ترانزيت اينترنت، ثبت نام دامنه، و ميزبانى وبّ ارائه مى كنند. خدمت دسترسى ارائهشده توسط ISP ها در سطوح داخلى و بينالمللى و از طريق اتصالات به يكديخر يا به مراكز واسطه انجام

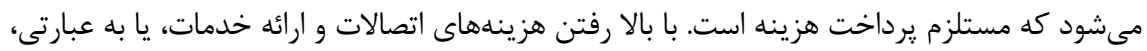
بالا رفتن هزينههاى اينترنت، كشورها به سمت راهكارهاى جديد براى كاهش هزينهها و در عين حال حفظ يا بهبود كيفيت ارائه خدمات رفتهاند. اولين كام در اين مسير، محلى كردن ارتباطات و اتصالات از طريق ايجاد يك بستر ارتباطى با نام نقاط تبادل ترافيك اينترنت بوده كه به كاهش هزينههاى ناشى

1. يورتهاى اترنت سريع (Fast Ethernet) از نرخ تبادل داده . . ا مكابيت در ثانيه يشتيبانى مى كنند، يعنى

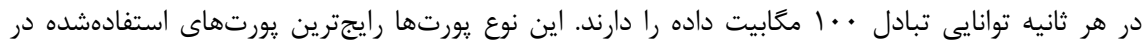

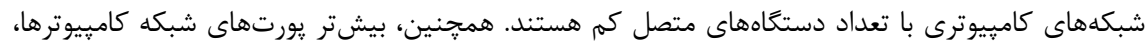

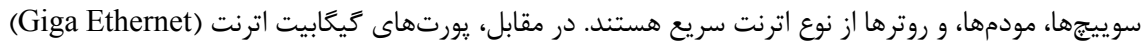

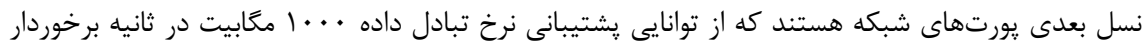

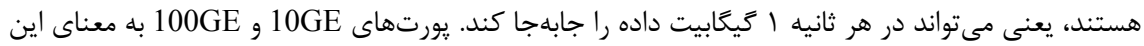

2. AS Number

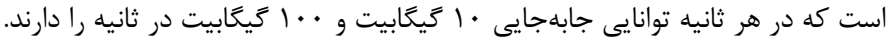

3. Web Hosting 
از اتصال به شبكههاى بينالمللى انجاميده است (Muttitanon \& Samanchuen, 2020). در شكل (Y)، كردش اطلاعات بين دو كاربر براى ارسال و دريافت ايميل نشان داده شده است. اخر IXP نباشد، ISP1 ايميل را از طريق ترانزيت بينالمللى، ابتدا به حامل بينالمللى ا ارسال مى كند و اين حامل، ايميل را از

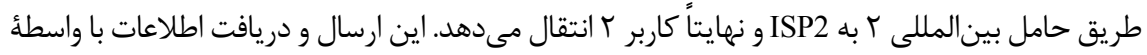
بينالمللى مستلزم يرداخت هزينه از سوى ISP هاى داخلى است. در صورتى كه با استقرار IXP در داخل، تبادل اطلاعات بين دو كاربر با اتصال مستقيم اين دو ISP از طريق IXP انجام مىشود.

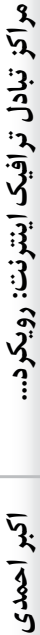

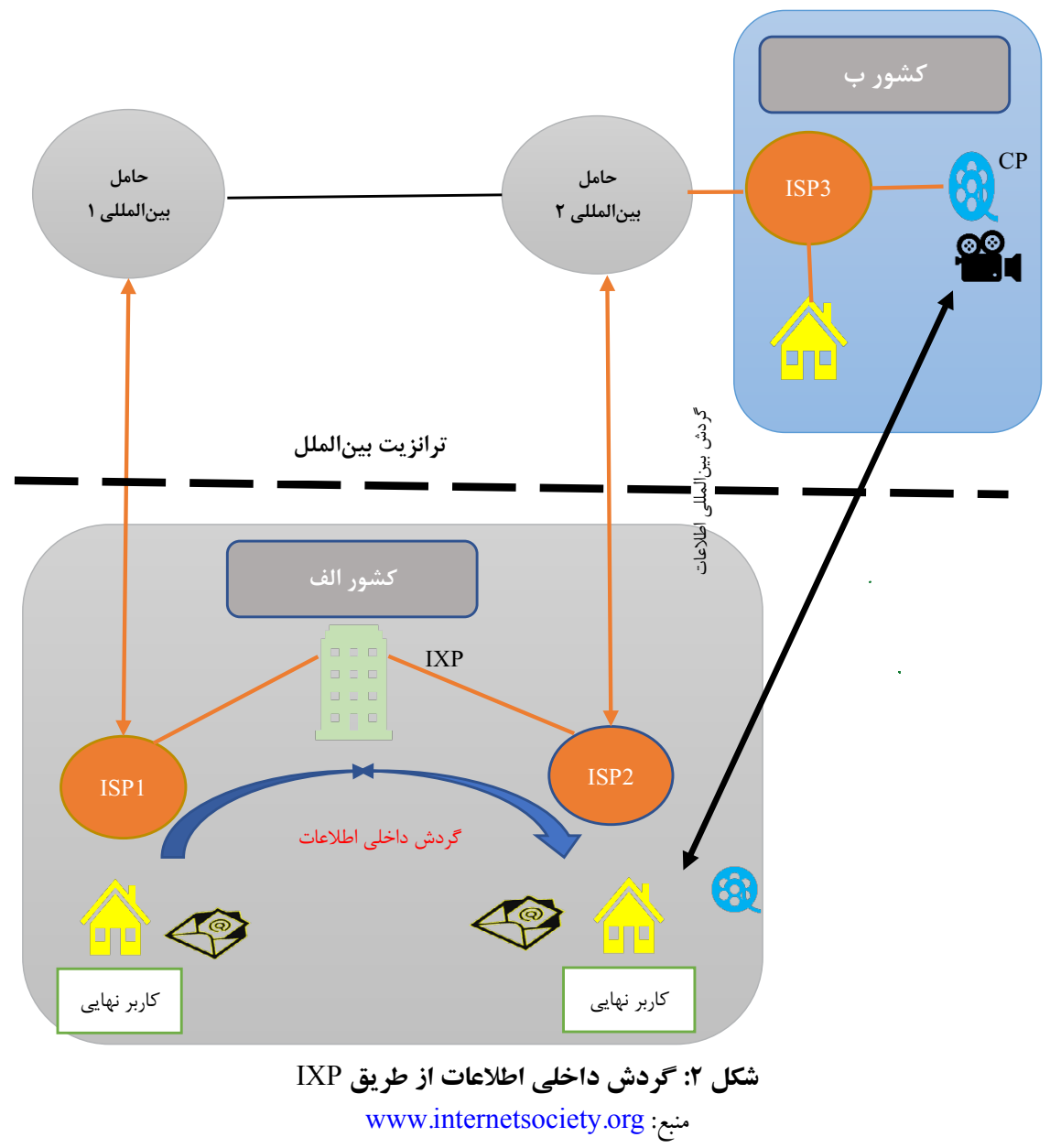


مهرمترين تجهيزات مورد نياز براى راهاندازى IXP كه بيشترين بار هزينهاى را نيز دارد، مربوط به سوييجها، كابل كشى و تجهيزات مسيريابى و انتقال است. هر يك از سوييجهاى مورد استفاده در نقاط تبادل ترافيك اينترنت داراى مشخصات خاصى هستند و بيشترين بار هزينهاى را در بخش تجهيزات سرمايهاى به خود اختصاص مى دهند. بلهطور معمول، براى راهاندازى يك نقطه تبادل ترافيك اينترنت مانند IXP مركز

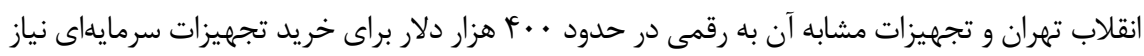

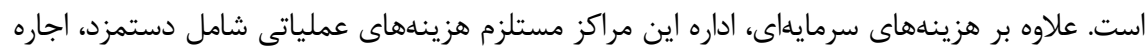

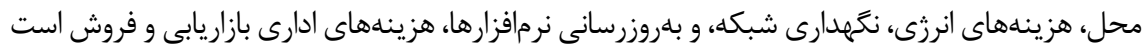

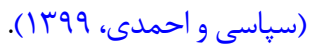

شركت ارتباطات زيرساخت بر اساس مصوبه سال | وبا شوراى عالى فضاى مجازى مجموعاً .

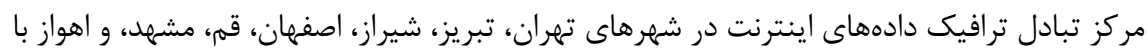

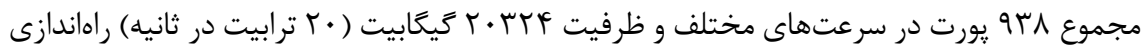

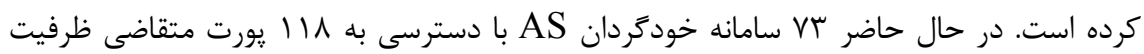

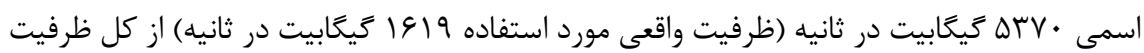
ايجادشده هستند (https:/tehran-ix.ir). اين مراكز به استناد سياستهاى مصوب شوراى عالى فضاى مجازى، امجاز به راهاندازى هيجزونه خدمات محتوايى يا دادهاى نظير موتور جستجو، دادهكاوى،

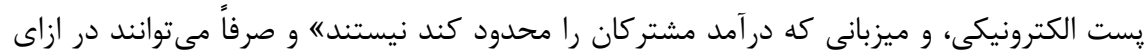
هزينههايى كه انجام مى دهند، از مشتر كان وجوهى اخذ كنند. اما جه خدماتى توسط اين مراكز ارائه

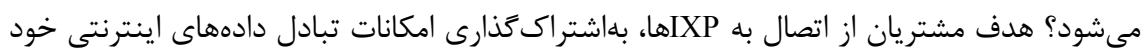

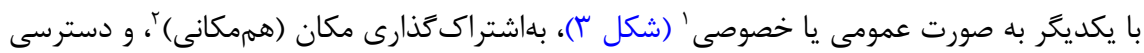

: در توافقات همتاسازى خصوصى، دو يا حند ايراتور شبكه با يكديكر توافق مى كنند كه . Private and Public Peering

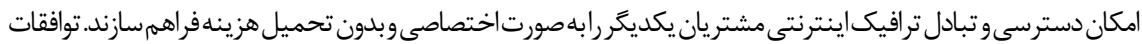

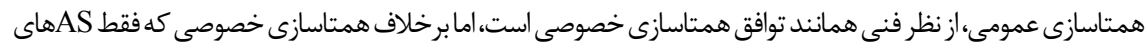

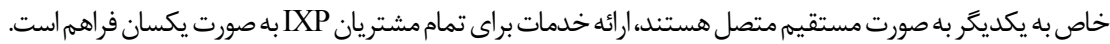

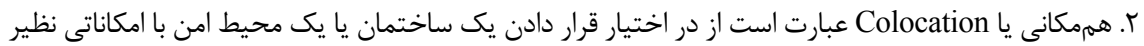

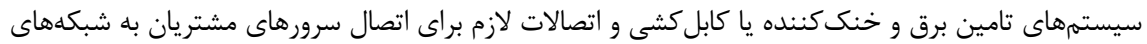

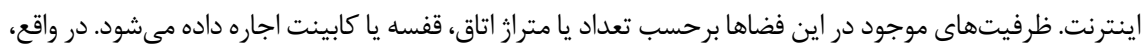

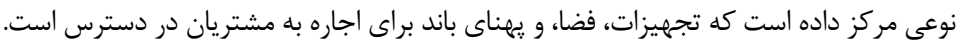


به مراكز داده و شبكههاى تحويل محتواست'.

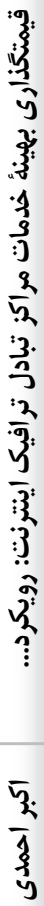

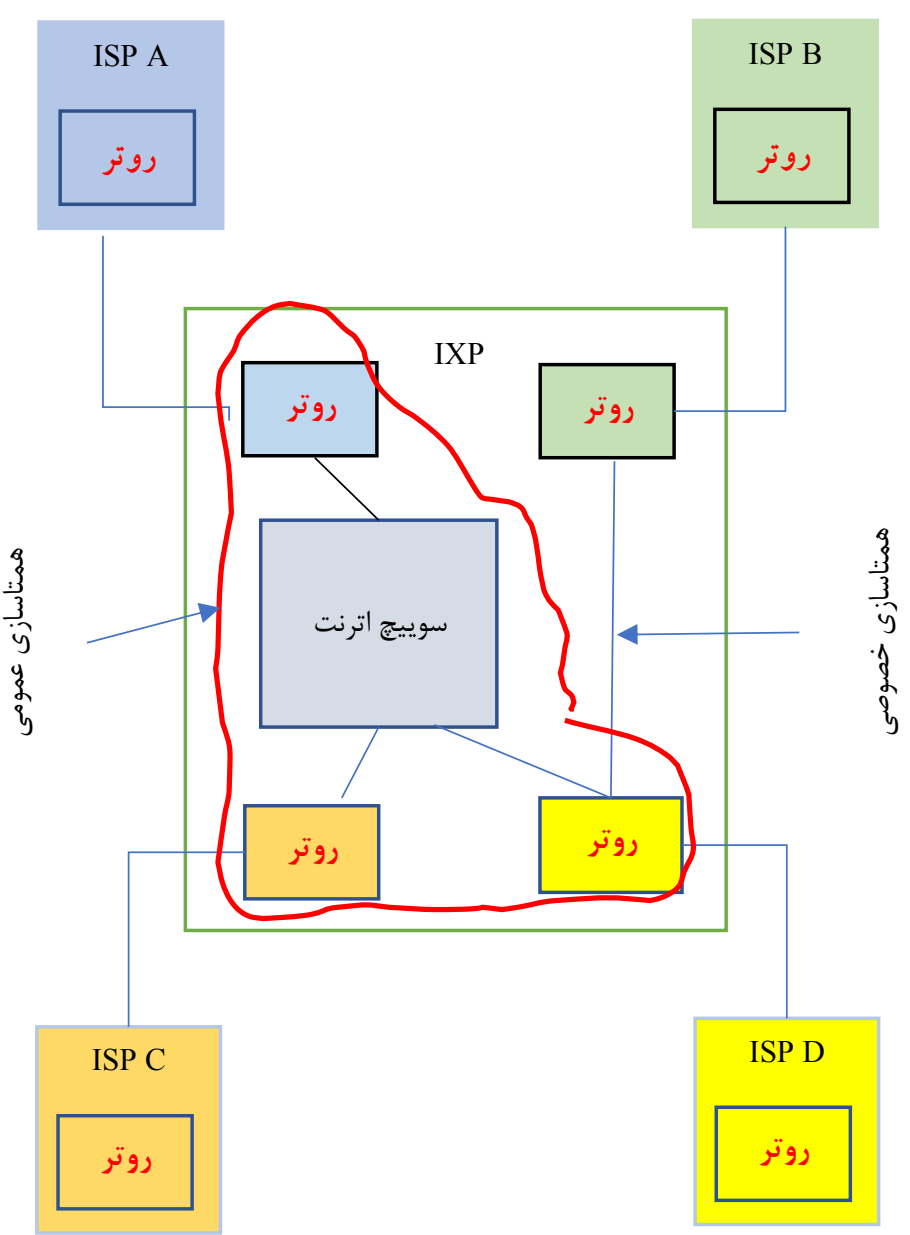

شكل rّ: نحوه اتصالات و همتاسازى خصوصى و عمومى در مراكز تبادل ترافيك اينترنت منبع: Www.internetsociety.org

ا. شبكه تحويل/توزيع محتوا (Content Delivery Network/ Content Distribution Network) شبكهاى

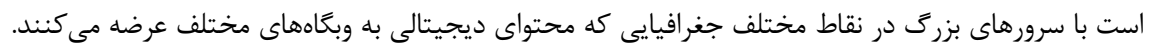

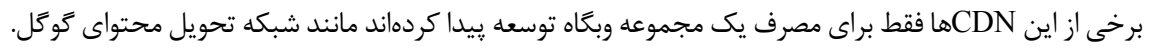


در مقابل اين هزينهها، انتظار مىرود كه مشتريان براى دريافت خدمات با كيفيت بهتر ضمن تمايل

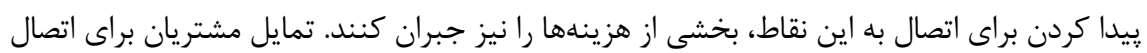

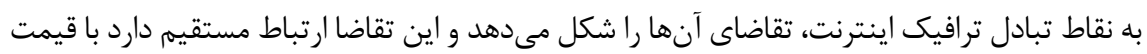
خدماتى كه دريافت مى كنند. سياسى و همكاران (99 (1)، بر اساس نظرسنجى انجامداده از مشتريان IXP

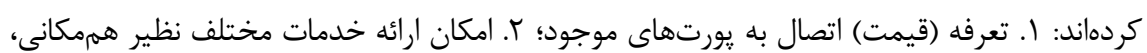

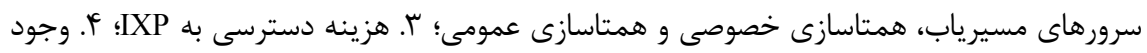

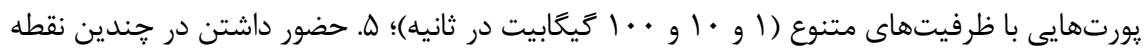

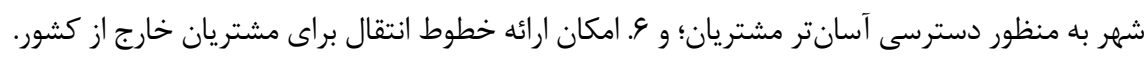

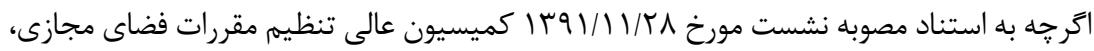
\از تاريخ راهاندازى نقاط تبادل ترافيك داده در كشور... اتصال متقابل شبكهها و تبادل ترافيك داده بين

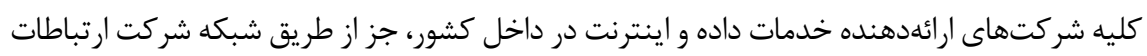

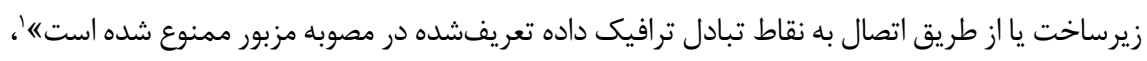

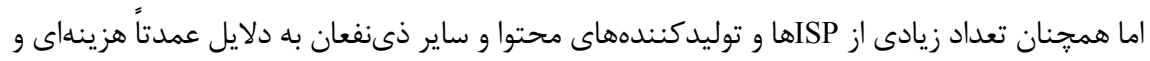

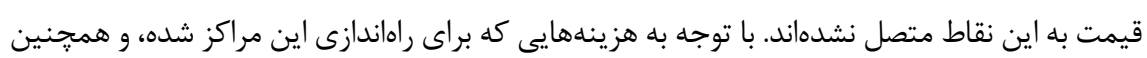

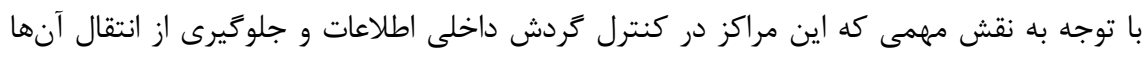

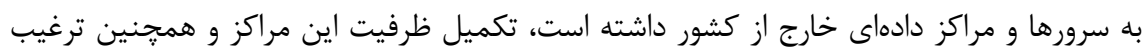

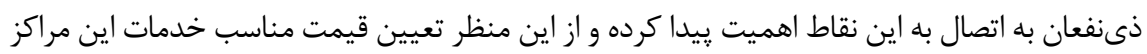

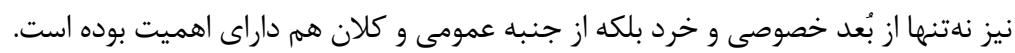

\section{قيمتخذارى خدمات نقاط تبادل ترافيك اينترنت (IXP)}

فرايند تعيين قيمت يك محصول يا خدمت در عمل شامل مراحل مختلفى از جمله تعيين هدف (مثلاً بيشينه كردن سود يا جلب رضايت مشترى يا كسب سهرم بازار)، تخمين تقاضا، تخمين هزينهانها،

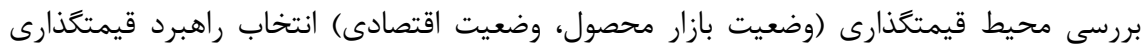


(مبتنى بر يوشش هزينه، مبتنى بر تامين تقاضاى بازار، مبتنى بر نياز مشتريان، مبتنى بر كشش قيمتى، قيمتخذارى محصول جديد)، و انتخاب تكنيك قيمتخذارى (بر اساس هدف و راهبردهاى تعيينشده) است. در علم اقتصاد، راهبردها و رويكردهاى متعددى براى تعيين قيمت كالا و خدمات وجود دارد كه از ميان آنها مىتوان به راهبردهاى قيمتخذارى معطوف به كمينهسازى هزينه، راهبردهاى قيمتخذارى معطوف به بيشينهسازى سود، و راهبردهاى قيمتخذارى مبتنى بر عرضه و تقاضا و ساختار بازار اشاره كرد. در راهبرد معطوف به هزينه، مهمترين اجزاى موثر بر خدمات اينترنتى

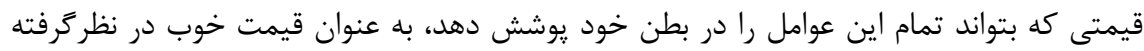

مىشود (He et al., 2012).

در راهبرد بيشينهسازى سود، با توجه به ساختار بازار و محيط قيمتخذارى، يس از تخمين توابع هزينه و تقاضا و محاسبه كشش قيمتى، عرضه كننده به محاسبه قيمتى كه متضمن بيشترين

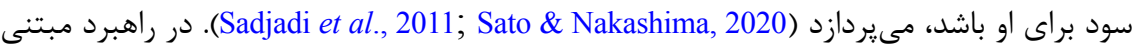
بر عرضه و تقاضا، قيمت خدمات متناسب با ساختار بازار و بر اساس الكوى عرضه و تقاضا تعيين مىشود. اين روشها كه مبتنى بر مدلسازى رياضى هستند، به دو روش عمده تقسيم مىشوند: بهينهيابى سيستمى و بهينهيابى راهبردى. هدف در الكوهاى بهينهيابى سيستمى، تعيين قيمتى

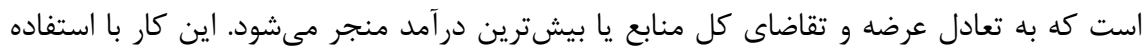

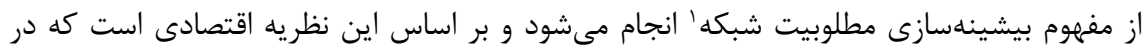

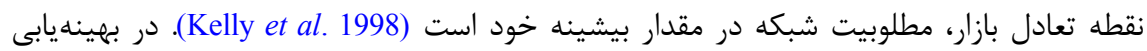

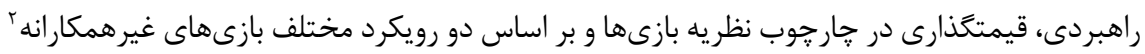

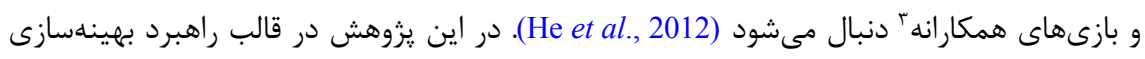

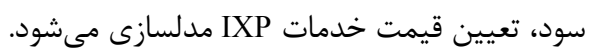
هر مركز تبادل ترافيك اينترنت داراى تعداد محدودى يورت قابلواگذارى روى سوييجهاى خود

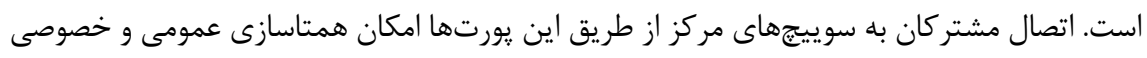

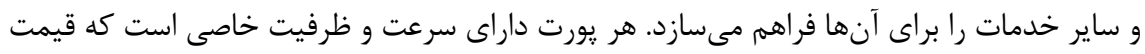

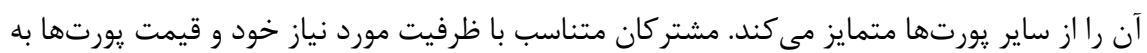

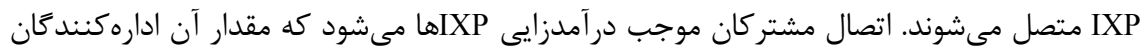

1. Network Utility Maximization (NUM) 
آنها را به ادامه فعاليتهاى خود و نحوه توسعه اين نقاط ترغيب يا دلسرد مى كند. مركز تبادل ترافيك

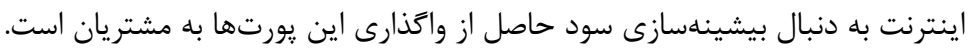

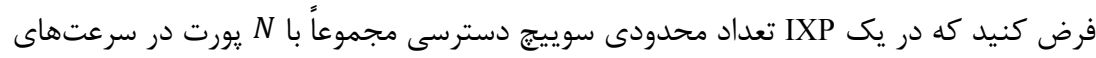
مختلف وجود دارد كه هر يك از آنها با قيمت سرعت يورتهاى IXP تقاضاى مشتريان براى هر يورت مستقل از يورتهاى ديگر است. تعداد

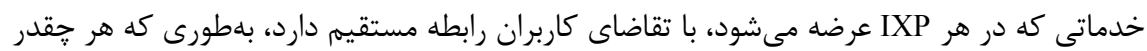

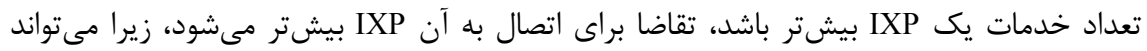
با مشتريان بيشترى از طريق اتصال و همتاسازى عمومى يا خصوصى، به تبادل اطلاعات بيردازد.

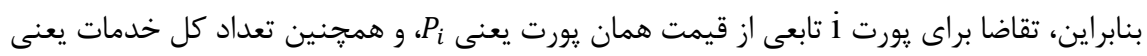

$$
Q_{i}=f\left(P_{i}, K\right) ; i=\{1,2, \ldots, \mathrm{N}\} \text { است، ئعنى }
$$

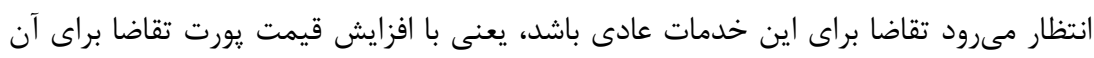

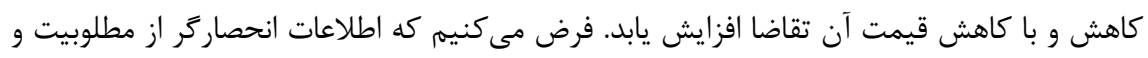
تقاضاى مشتريان كامل است. تابع هدف: آر در هر بردار قيمتى مانند

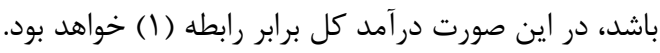

$R=\boldsymbol{P}^{\prime} \boldsymbol{Q}=\sum_{i=\mathbf{1}}^{N} P_{i} Q_{i}$

از طرف ديكر، مهمترين بخش هزينه IXP مربوط به تجهيزات آن است كه فرض شده است بهطور

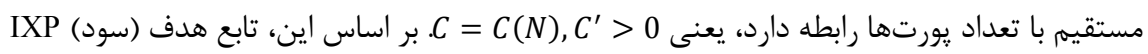
به شكل رابطه (r) خواهد بود:

$\pi=\boldsymbol{P}^{\prime} \boldsymbol{Q}(P, K)-\mathrm{C}(\mathrm{N})$

هدف انحصارگر بيشينهسازى سود است. اما سود IXP بايد نسبت به برخى قيود و محدوديتهاى فيزيكى و قانونى آن بيشينه شود. اولين قيد مسئله مربوط به ظرفيت IXP است. كل تقاضا نمىتواند بيشتر از ظرفيت كل در اين مراكز قابل تخصيص باشد. يعنى N S N

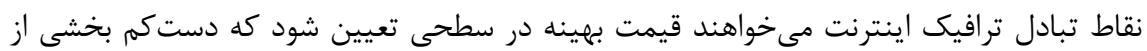
ظرفيت ايجادشده براى هر يورت مورد استفاده قرار گيرد. فرض كنيد مديران IXP بخواهند دست كم < 100 > 0 درصد از ظرفيت كل توسط مشتر كان جذب شود، يعنى: قيد خواهيم داشت: 
از سوى ديگر، قيمت بهينه بايد بهُونهاى تعيين شود كه علاوه بر يوشش هزينه نهايى، از مقدار معينى از متوسط قيمتهاى IXP بنابراين، مسئله IXP حل برنامه (ז) است:

Max $\pi=\boldsymbol{P}^{\prime} \boldsymbol{Q}(P, K)-\mathrm{C}(\mathrm{N})$

s.t.

$\delta \mathrm{N} \leq Q(P, K) \leq \mathrm{N}$

$\frac{\partial C}{\partial N} \leq P_{i} \leq(1+\mu) \bar{P}_{i} ; \forall \mathrm{i}=1, \ldots, N$

كه با انجام جند محاسبه ساده مى توان برنامه (r) را به شكل مسئله برنامهريزى (ז) تبديل كرد:

Min $-\pi=\mathrm{C}(\mathrm{N})-\boldsymbol{P}^{\prime} \boldsymbol{Q}(P, K)$

s.t.

$\delta \mathrm{N}^{-1}(P, K) \leq 1$

$\mathrm{N}^{-1} \boldsymbol{Q}(P, K) \leq 1$

$\frac{\partial C}{\partial N} \cdot P^{-1} \leq 1$

$P_{i}\left[(1+\mu) \bar{P}_{i}\right]^{-1} \leq 1 ; \forall \mathrm{i}=1, \ldots, N$

$\delta, \mu, G>0$

برنامه (\&))، يك مسئله بهينهيابى رياضى است و از روشهاى مختلفى مىتوان آن را حل كرد. اما

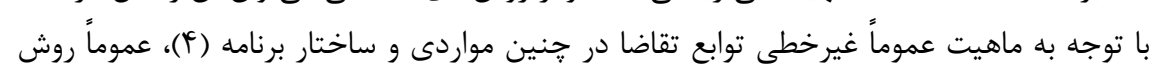

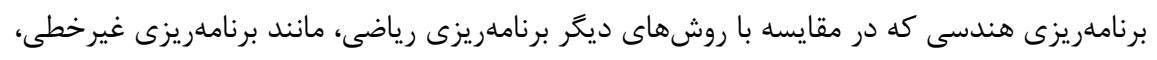
از كارايى بيشترى برخوردار است، بكار گرفته مىشود (Rao, 2019).

\section{روش اشناسى ثزوهش}

اين :ززوهش از منظر هدف كاربردى، از منظر كردآورى دادهها پيمايشى، و از منظر تكنيك

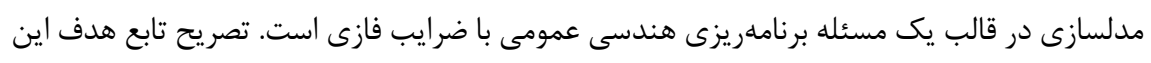

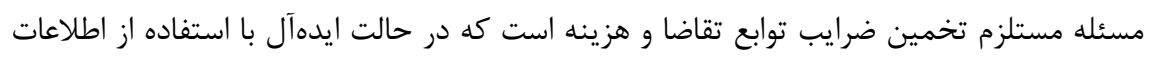

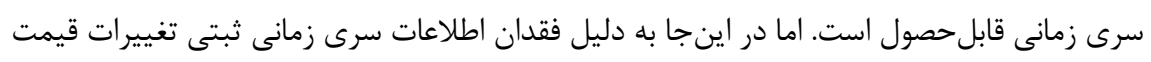
و تقاضا براى اتصال به IXPIهاى كشور، تخمين ضرايب مزبور با استفاده از دادههاى مقطعى مربوط

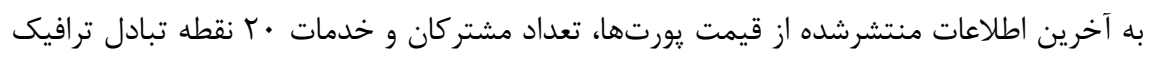

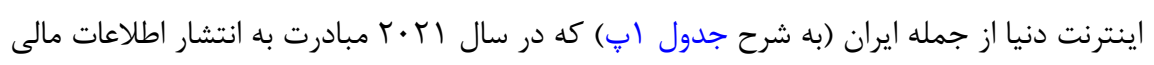


و اقتصادى خود مىكنند، انجام شده است. بسيارى از هاى دنيا به دلايلى از انتشار اطلاعات و

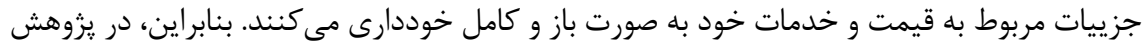

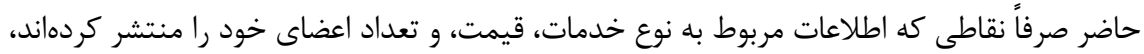
از طريق مراجعه به سايت آنها به صورت مستقل به عنوان نمونه انتخاب شدهاند. از سوى ديگر،

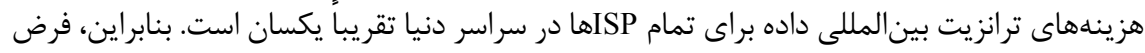

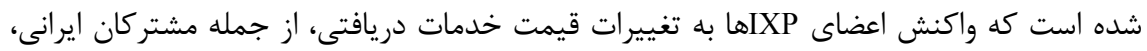
مشابه است. اين كه تا جه حد خطاى برآورد در كشش قيمتى تقاضا بر نتايج مدل و قيمتهاى بهـئه اثر مى گذارد، در بخش تحليل حساسيت بررسى شده است. پيس از جمعآورى اطلاعات تخمين ضرايب

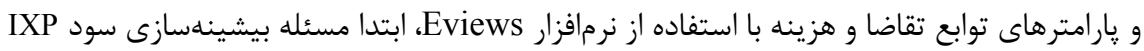
هاى كشور با توجه به قيدهاى مربوطه در قالب الكَوى برنامهريزى هندسى با ضرايب قطعى و ضرايب

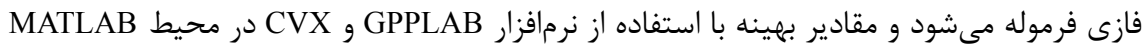
محاسبه و با قيمتهاى فعلى ابلاغى مقايسه مى شوند.

\section{برنامهريزى هندسى}

برنامهريزى هندسى در كنار روشهاى كلاسيك بهينهيابى مبتنى بر حسابان، حساب تغييرات و كنترل بهينه، برنامهريزى غيرخطى، برنامهريزى درجه دو، برنامهريزى يويا، برنامهريزى عدد صحيح،

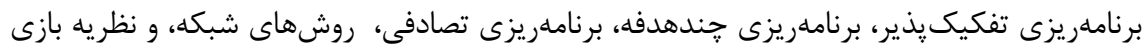

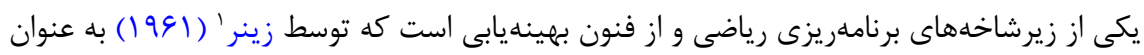
روشى براى حل گروهى از معادلات غيرخطى مهندسى، كه توابع آنها مجموعى از توابع خطى -

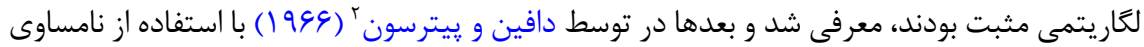

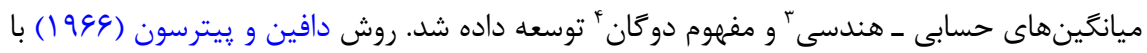

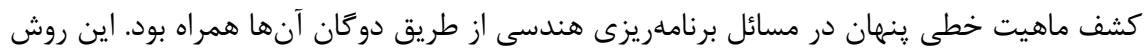
براى مواردى كه با كمينهسازى توابعى به شكل جندجملهاى غيرخطى مثبت نسبت به قيودى از همان نوع مواجه هستيم، بكار مىرود. تفاوت اين روش با ساير روشهاى بهينهيابى اين است كه در

\section{Zener}

2. Duffin \& Peterson

3. Inequality of Arithmetic-Geometric Means

4. Dual 
اين نوع مدلسازى، بهجاى متغيرهاى تصميم، بر اندازه و مقدار نسبى هر يك از جملات تابع هدف

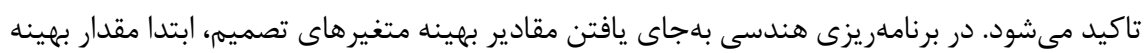
تابع هدف محاسبه مىشود، بهويزه اين روش براى مواردى كه يافتن مقدار هدف بيشتر از متغيرهاى

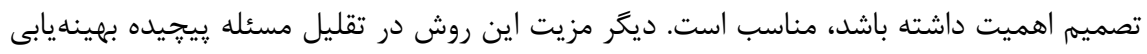

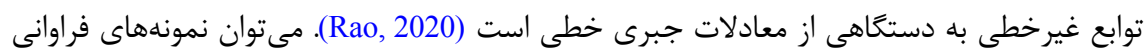

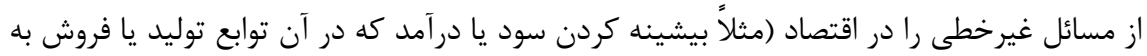

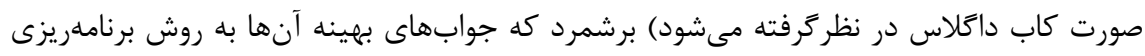
هندسى بلدست مى آيد. برنامهريزى هندسى به صورت يك مسئله بهينهابيى نامقيد يا مقيد تعريف مىشود. ضرايب و يارامترهاى اين نوع برنامهريزى مىتوانند به صورت قطعى، فازى يا تصادفى در

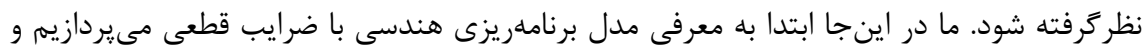
سيس الكوى فازى آن را مطرح مى كنيم.

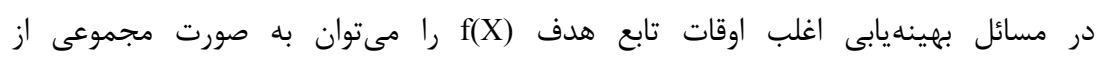
جزء م (j=1,..,N) 政 $U_{j}(\boldsymbol{X})=c_{j} x_{1}^{a_{1 j}} \ldots x_{n}^{a_{n j}}$

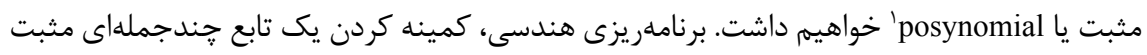
به شكل رابطه (ه) است.

Min $y=f(\boldsymbol{X})=\sum_{j=1}^{N} c_{j} U_{j}(\boldsymbol{X}) \quad, \quad \boldsymbol{X}=\left[\begin{array}{llll}x_{1} & x_{2} & \cdots & x_{n}\end{array}\right]^{T}$

نقطه بهينه را مىتوان با روشهاى كلاسيك بهينهيابى (مشتق مرتبه اول نسبت به X) بهدست

$\nabla f\left(\boldsymbol{X}^{*}\right)=\left[\sum_{j=1}^{N} \frac{\partial U_{j}}{\partial x_{1}}, \ldots, \sum_{j=1}^{N} \frac{\partial U_{j}}{\partial x_{n}}\right]^{T}=\left[\frac{1}{x_{1}} \sum_{j=1}^{N} a_{1 j} c_{1} \prod_{i=1}^{n} x_{i} a_{i j}, \ldots, \frac{1}{x_{n}} \sum_{j=1}^{N} a_{n j} c_{j} \prod_{i=1}^{n} x_{i} a_{i j}\right]^{T}=\mathbf{0}$ اگر تعداد جملات با تعداد متغيرهاى تصميم به اضافه يك برابر باشد، در آن صورت جواب يكتا

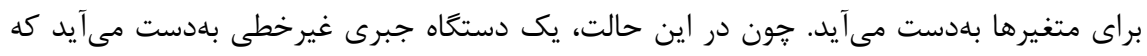

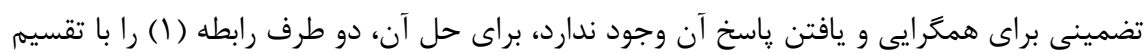
بر (X) مى كنند. 
$w_{j}=c_{j} \prod_{i=1}^{n}\left(x_{i}^{a_{i j}} / y\right)=\frac{U_{j}(\boldsymbol{X})}{y}$

مجموع وزنهاى فوق براى تمام زها برابر ا است كه بهطور ساده از تعريف تابع جندجملهاى

$\sum_{j=1}^{n} w_{j}=\sum_{j=1}^{N}\left[c_{j} \prod_{i=1}^{n}\left(x_{i}^{a_{i j}} / y\right)\right]=1$

مثبت نتيجه مىشود.

معادله (^) را شرط تعامد' گويند. با در نظرگرفتن شرط لازم براى حل مسئله و تعريف فوق

$\sum_{j=1}^{N} a_{i j} w_{j}=0, \quad \forall i=1,2, \ldots, n$

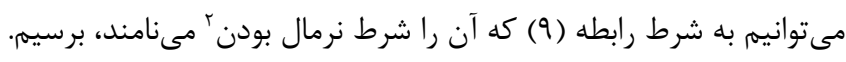

با استفاده از شرط تعامد و تعريف وزن نسبى مىتوانيم تابع هدف را به صورت رابطه (• () تعريف

$y=y^{\sum w_{j}}=\prod_{j=1}^{N} y^{w_{j}}=\prod_{j=1}^{N}\left(\frac{U_{j}(X)}{w_{j}}\right)^{w_{j}}=\prod_{j=1}^{N}\left(\frac{c_{j}}{w_{j}}\right)^{w_{j}} \prod_{j=1}^{N} \prod_{i=1}^{n} x_{i} a_{i j} w_{j}$

آخرين عبارت فوق كه به صورت ضرب دوكانه ظاهر شده است را مىتوان به شكل سادهترى

$\prod_{j=1}^{N} \prod_{i=1}^{n} x_{i} a_{i j w_{j}}=\prod_{i=1}^{n} x_{i}^{\left(\sum_{j=1}^{N} a_{i j} w_{j}\right)}$

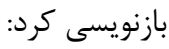

در نتيجه، تابع هدف در نقطه بهينه عبارت خواهد بود از:

$y^{*}=\prod_{j=1}^{N}\left(\frac{c_{j}}{w_{j}^{*}}\right)^{w_{j}^{*}} \prod_{i=1}^{n} x_{i}^{\left(\sum_{j=1}^{n} a_{i j} w_{j}^{*}\right)}=\prod_{j=1}^{N}\left(\frac{c_{j}}{w_{j}^{*}}\right)^{w_{j}^{*}}$

با توجه به رابطه (9) وزنهاى نسبى w $w_{j}$

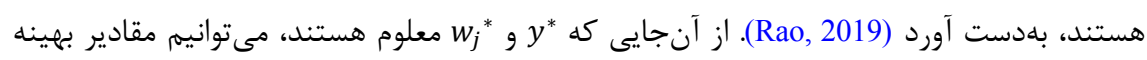
متغيرهاى تصميم را از رابطه (V) بهدست آوريم.

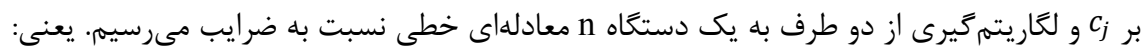
$\ln \left(\frac{w_{j}{ }^{*} y^{*}}{c_{j}}\right)=a_{1 j} \ln \left(x_{1}{ }^{*}\right)+\cdots+a_{n j} \ln \left(x_{n}{ }^{*}\right)$

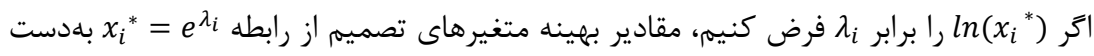

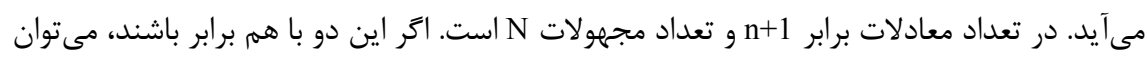


به جواب يكتا براى مسئله دست يافت. كمّيت N-n-1 را در برنامهريزى هندسى درجه سختى' مىنامند و با df نشان مى دهند. در حالتهاى عمومىتر، ضرايب تابع هدف ممكن است داراى علامت منفى باشند. براى مثال، بيشينه كردن تابع سود مستلزم نسبت دادن ضرايب منفى به تابع هزينه است، بنابراين از حالت جندجملهاى مثبت خارج مىشود. در اين شرايط، با شكل عمومىتر مدلهاى

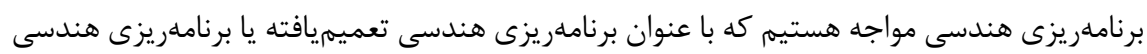

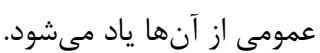

\section{برناملريزى هندسى عمومى}

يك مدل برنامهريزى هندسى مقيد عمومى با m قيد نامساوى در حالت كلى به صورت رابطه

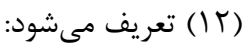

$\operatorname{Min} \underset{x}{y}=\sum_{j=1}^{N_{o}} \sigma_{o j} c_{o j} \prod_{i=1}^{n} x_{i}^{a_{o i j}}$

s.t.

$g_{k}(\boldsymbol{x})=\sum_{j=1}^{N_{k}}\left(\sigma_{k j} \beta_{k j} / \sigma_{k}\right) \prod_{i=1}^{n} x_{i}^{\gamma_{k i j}} \leq 1, \quad k=1, \ldots, m$, $x_{j}>\circ, \quad j=1, \ldots, N_{k}$.

كه در آن m: تعداد قيود مسئله، n: تعداد متغيرهاى تصميم،

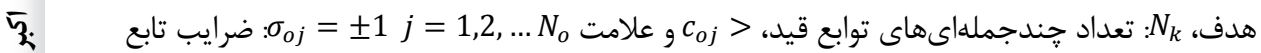
هدف، 0 > > علامت بَ اشاره دارند.

اگر توابع علامت مثبت و منفى باشند، مسئله فوق را برنامهريزى هندسى signomial مىنامند.

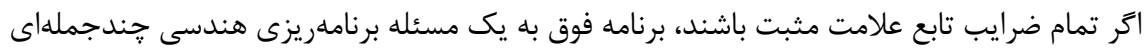

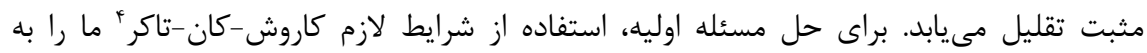
سيستمى از معادلات غيرخطى مىرساند كه حل آنها دشوار است. اما مى توان با تبديل مئل مسئله اوليه

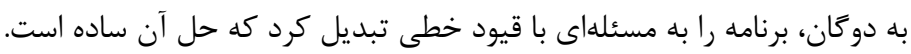

$\operatorname{Max} d(\boldsymbol{w})=\prod_{j=1}^{N_{k}}\left(\frac{c_{o j}}{w_{o j}}\right)^{w_{o j} \sigma_{o j}} \prod_{j=1}^{N_{k}}\left(\frac{\beta_{k j}}{w_{k j}}\right)^{w_{k j} \sigma_{k j}} \prod_{k}^{m} \sum_{j}^{N_{k}}\left(w_{k j}\right)^{\sum_{j}^{N_{k}}\left(w_{k j}\right)}$

1. Degree of Difficulty

2. General Geometric Programming

19

3. Signum Functions

4. Karush- Kuhn-Tucker 


\section{Subject to:}

$$
\begin{aligned}
& \sum_{j=1}^{n} \sigma_{i j} w_{j}=1, \quad \forall i=0,1,2, \ldots, n \\
& \sum_{j=1}^{N} \sigma_{i j} a_{i j} w_{j}=0, \quad \forall i=0,1,2, \ldots, n \\
& w_{j}>0 \\
& \text { بلهدست آورد. }
\end{aligned}
$$

\section{برنامهريزى هندسى با هارامترهاى فازى}

در برنامهريزى هندسى با پارامترهاى فازى ضرايب تابع هدف و قيدها، به صورت اعداد فازى در نظركرفته مى شوند. در اين يزوهش از اعداد فازى مثلثى به شكل

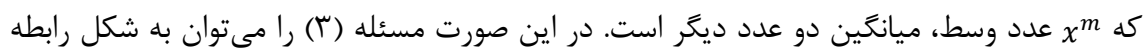

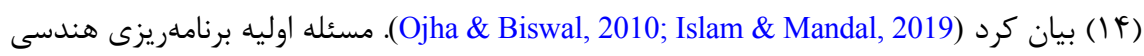
با پارامترهاى جند

$\operatorname{Min} \sum_{j=1}^{N_{o}} \tilde{c}_{o j} \prod_{i=1}^{n} x_{i}^{\tilde{a}_{i j}}$

s.t. $\sum_{j=1}^{N_{i}} \tilde{c}_{k j} \prod_{i=1}^{n} x_{i} \tilde{a}_{i j} \leq 1 ; x_{j} \geq 0 ; k=1,2, \ldots, m$

كه در آن ضرايب در تابع هدف و قيدها اعداد فازى مثلثى هستند. براى هر تركيب سهتايى تابع هدف متناظر با هر مقدار عبارت است از $\left(\tilde{c}_{o}, \tilde{c}_{k}, \tilde{a}\right)$ y

$$
\begin{aligned}
& y^{l}=\operatorname{Min}_{x} \sum_{j=1}^{N_{o}} c_{o j}^{l} \prod_{i=1}^{n} x_{i} a_{i j}^{l} \\
& \text { s.t. } \quad \sum_{j=1}^{N_{i}} c_{k j}^{l} \prod_{i=1}^{n} x_{i}^{a_{i j}^{l}} \leq 1 ; k=1,2, \ldots, m \\
& y^{u}=\operatorname{Min}_{x} \sum_{j=1}^{N_{o}} c^{u}{ }_{o j} \prod_{i=1}^{n} x_{i} a_{i j}^{u} \\
& \text { s.t. } \sum_{j=1}^{N_{i}} c_{k j}^{u} \prod_{i=1}^{n} x_{i} a_{i j}^{u} \leq 1 ; k=1,2, \ldots, m \\
& y^{m}=\operatorname{Min}_{x} \sum_{j=1}^{N_{o}} c^{m}{ }_{o j} \prod_{i=1}^{n} x_{i} a_{i j}^{m} \\
& \text { s.t. } \sum_{j=1}^{N_{i}} c_{k j}^{m} \prod_{i=1}^{n} x_{i} a_{i j}^{m} \leq 1 ; k=1,2, \ldots, m
\end{aligned}
$$

ميانگين حسابى اين سه مقدار برابر است با برابر 
كمينهسازى كمّيتى مانند ס در نظر كرفت كه كوجىتر يا مساوى هدف نيز به صورت قيد به مسئله اضافه شود، يعنى:

s.t.

$\frac{y^{l}+y^{m}+y^{u}}{3} \leq \delta$

$\sum_{j=1}^{N_{o}} c^{l}{ }_{o j} \prod_{i=1}^{n} x_{i} a_{i j}^{l} \leq y^{l}$

$\sum_{j=1}^{N_{o}} c^{u}{ }_{o j} \prod_{i=1}^{n} x_{i} a_{i j}^{u} \leq y^{u}$

$\sum_{j=1}^{N_{o}} c^{m}{ }_{o j} \prod_{i=1}^{n} x_{i} a_{i j}^{m} \leq y^{m}$

$\sum_{j=1}^{N_{i}} c_{k j}^{m} \prod_{i=1}^{n} x_{i} a_{i j}^{m} \leq 1 ; k=1,2, \ldots, m$

برنامه (ه|) با تبديل جهار قيد ابتدايى به حالت نامساوى (كوجكتر از () به يك مسئله

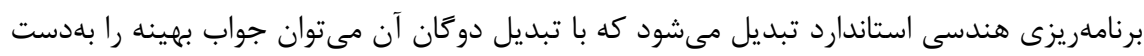

آورد (Islam \& Mandal, 2019).

مرورى بر ثيخوهش هاى بيشين

در اين بخش نكاهى به خُند يزوهش كه به الكوهاى قيمتخذارى بهينه خدمات اينترنت يا

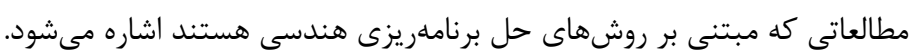

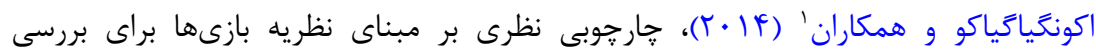

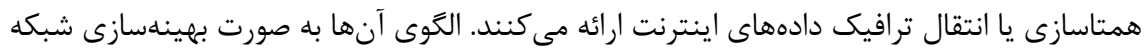

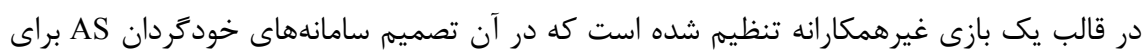

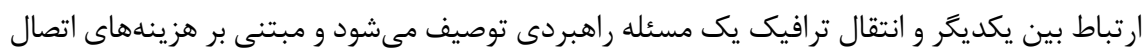

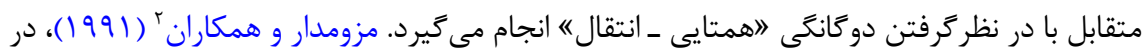
جار جوب نظريه بازىها، موضوعات انصاف را در قيمت خدمات شبكههاى ارتباطى بررسى ميى كنيند. آنها مطرح مى كنند كه در بازىهاى غيرهمكارانه، افراد به صورت مستقل و بدون توجه به به واكنش 
ديكران، راهبردهاى خود را انتخاب مى كنند كه اين مسئله اگرخه تعادل نش' را به صورت محض

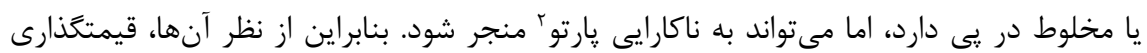
از طريق فرمولبندى مسئله در قالب يك بازى همكارانه ارجح است. در انتها نتيجهاى كه ميى ميرند اين است كه راهحل جانهزنى نش، كانديداى مناسبى براى دستيابى به يك نقطه عملياتى منصفانه

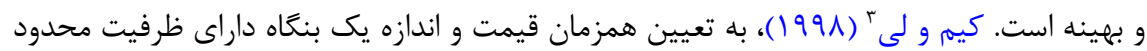
با هدف بيشينه كردن سود بنعاه مىيردازند. اين دو از مدل برنامهريزى هندسى مقيد براى تعيين

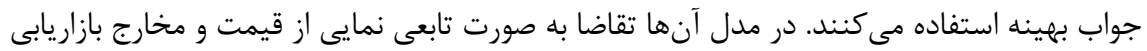

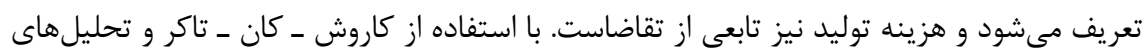

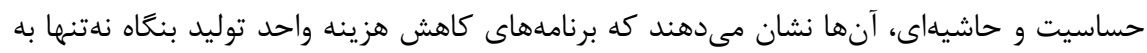

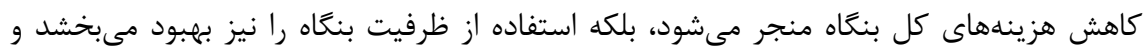
در نهايت موجب افزايش سود بنكاه مى از موجودى انبار در قالب مسئله برنامهريزى هندسى، به تعيين مقدار بهينه قيمت خريد و فروش

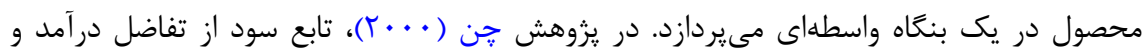

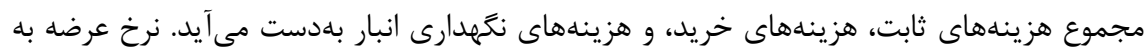

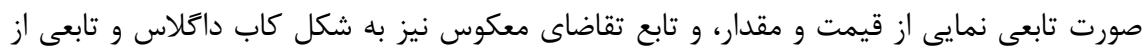

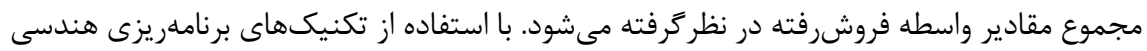
و روش دوكان، قيمتهاى بهينه فروش و خريد محصول بهدست آمده است. يو و همكارانه (9 .ا؟)، از يك مدل برنامهريزى عدد صحيح مقيد براى تخصيص يهناى باند اينترنت استفاده مىكنند تا

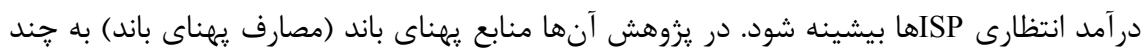

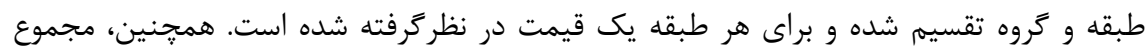

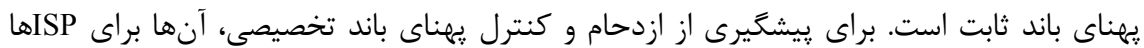

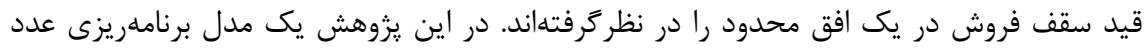
صحيح مقيد معرفى شده و با الكوريتم (بهينهسازى ازدحام ذرات") مقادير بهينه را محاسبه كردهاند.

1. Nash Equilibrium

2. Pareto Inefficiency

3. Kim \& Lee

4. Chen

5. You et al.

6. Particle Swarm Optimization (PSO) 
سجادى و همكاران (II ( إ)، به تعيين قيمت بهينه خدمات ISP با استفاده از برنامهريزى هندسى فازى مى يردازند. آنها ابتدا مدل رياضى قيمتگذارى خدمات ADSL را در قالب يك الكَى برنامهريزى هندسى با هدف بيشينهسازى درآمد ISP فرموله مى كنند و سيس با تبديل ضرايب و وارارامترهاى تابع تقاضا در مدل قطعى به اعداد فازى مثلثى، با دادههاى فرضى مدل را با كمك نرمافزار

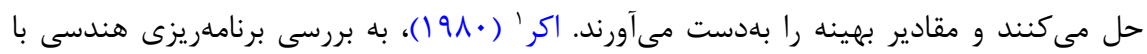

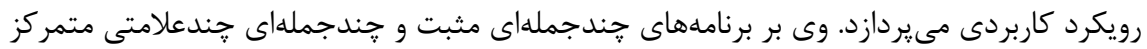
است. هدف يزوهش او، ارائه شناخت جامعى از نتايج اساسى برنامهريزى هندسى به خواننده از طريق

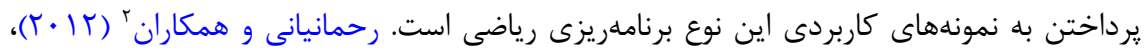

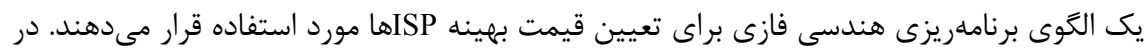
يروهش آنها تقاضا براى يك خدمت ISP به صورت تابعى نمايى از قيمت با اثر معكوس و مخارج بازاريابى با اثر مثبت در نظرگرفته مىشود. يزوهشگران با در نظركرفتن قيدهاى بودجهاى بازاريابى و

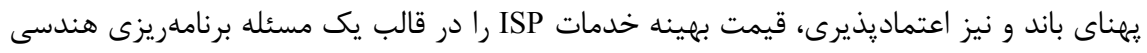

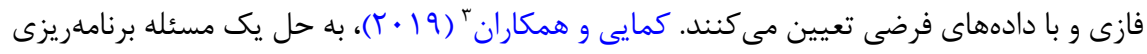

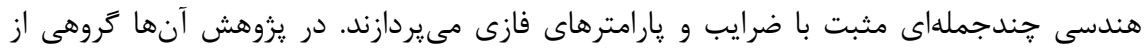

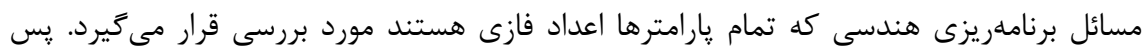

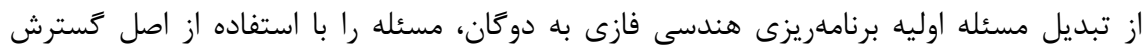

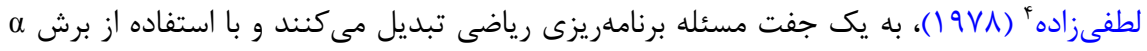
در تابع هدف و برش r در محدوديتهاى فرم دوكان برنامهريزى هندسى، مقادير بهينه را در سطح قابل قبولى از $\alpha$ و r بdدست مي مآورند.

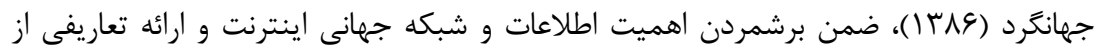
شبكههاى ارتباطى، به موضوع قيمتحذارى در شبكهها، انواع روشهاى نظرى قيمتحذارى مانند

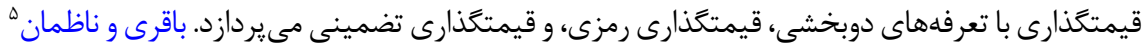

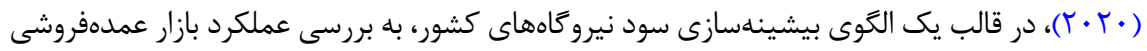

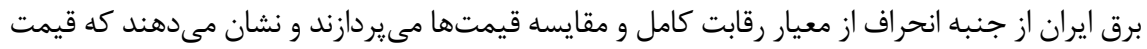

\section{Ecker}

2. Rahmaniani et al.

3. Kamaei et al. 


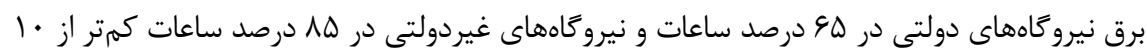

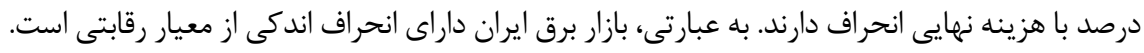

\section{تحليل دادهها و حل مدل}

\section{مدل تعيين قيمت با ضرايب قطعى}

در خارجوب مدل برنامهريزى (\{)، ابتدا بايد تابع هدف يعنى تابع تقاضا و تابع هزينه را تصريح

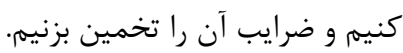

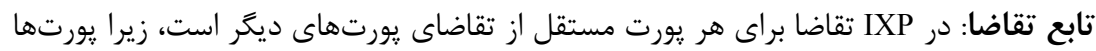

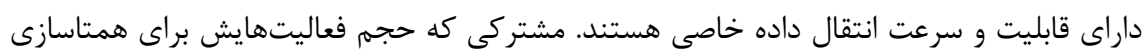

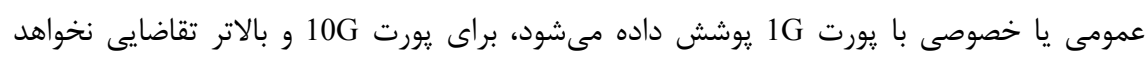

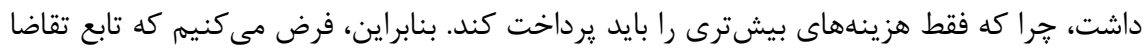
براى هر يورت به شكل خدمات قابلارائه فعلى IXP است. با فرض نرمال بودن تقاضا براى اتصال به IXP و واستفاده از خدمات

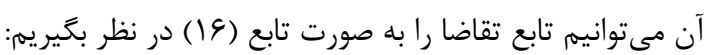

$Q(P, K)=A P^{-\alpha} K^{\beta}$

كه در آن م كشش قيمتى تقاضا و م كشش تقاضا نسبت به تعداد خدمات موجود در IXP و

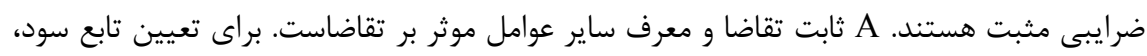
لازم است هزينه اين نقاط را در نظر بخيريهم.

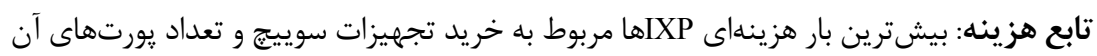

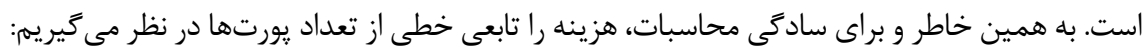
$C(N)=c N ; c \geq 0$

كه در آن C متوسط هزينه واحد هر يورت (و در اين حالت خاص برابر هزينه نهايى يورت) و تعداد كل يورتهاست.

مدل قطعى تعيين قيمت خدمات IXP: با توجه به توضيحاتى كه در بخش مبانى نظرى اركائه بائه شد،

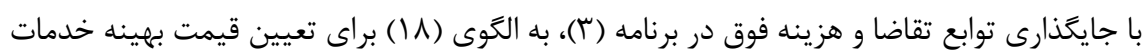
IXP 
$\operatorname{Max} \pi=A P^{1-\alpha} K^{\beta}-c N$

Subject to

$\delta N \leq A P^{-\alpha} K^{\beta} \leq N$

: $\quad c \leq P \leq(1+\mu) \bar{P}$

$(\mu, \alpha, \beta, \delta) \in \mathbb{R} ;(A, P, c, K, N, \bar{P}) \in \mathbb{R}^{+}$

مدل (1))، كه در آن ضرايب تابع هدف منفى هم هستند، يك مدل از نوع برنامهريزى هندسى

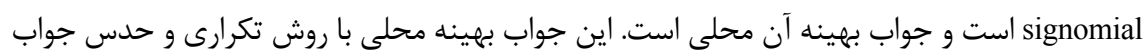

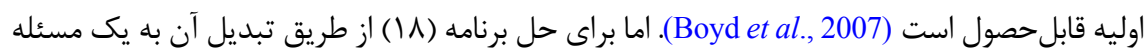

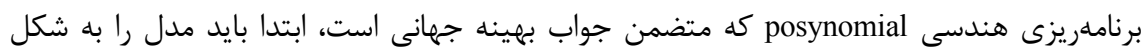
استاندارد (^) تبديل كنيم. جون تابع هدف از نوع سود است و سود منفى (زيان) مورد نظر عرضه كننده نيست، بنابراين متغير مثبت ناصفرى مثل G را در نظر مى كيريم و تابع هدف را را به شكل

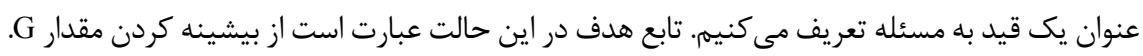
لم ا: فرض كنيد

$\operatorname{Max} G$ شدنى * معادل مسئله بهينه يابى مقيد (9 (1) است:

s.t.

$f(x) \geq G$

$G>0$

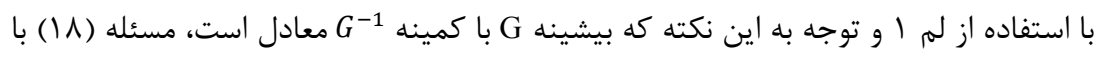

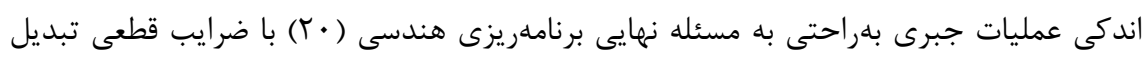

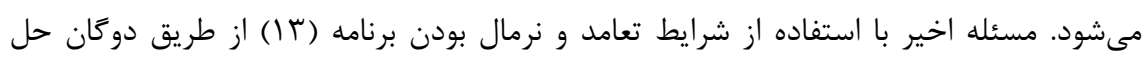
مى شود:

$\operatorname{Min} G^{-1}$

S.t:

$G A^{-1} P^{\alpha-1} K^{-\beta}+c N A^{-1} P^{\alpha-1} K^{-\beta} \leq 1$

$N^{-1} A P^{-\alpha} K^{\beta} \leq 1$

$\delta N A^{-1} P^{\alpha} N^{-\beta} \leq 1$

$[(1+\mu) \bar{P}]^{-1} P \leq 1$

$c P^{-1} \leq 1$

$(\mu, \alpha, \beta, \delta) \in \mathbb{R} ; \quad(A, P, c, K, N, \bar{P}, G, F C) \in \mathbb{R}^{+}$

ra 


\section{مدل تعيين قيمت بهينه فازى}

براى لحاظ كردن ناطمينانى و خطاى اندازهيرى، در اين بخش يارامتر A و كششهاى تابع تقاضاى

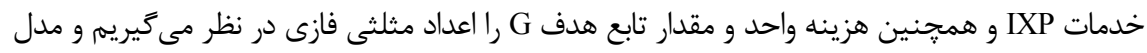

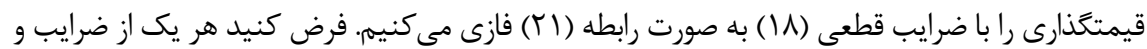
يارامترهاى مسئله به صورت

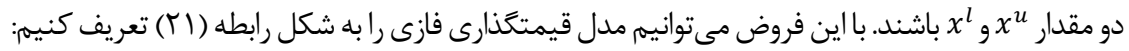
$\left(G^{l}, G^{m}, G^{u}\right) \operatorname{Max} \tilde{G}=$

St:

$$
\begin{aligned}
& \tilde{A} P^{1-\widetilde{\alpha}} K^{\widetilde{\beta}}-\tilde{c} N \geq \tilde{G} \\
& N^{-1} \tilde{A} P^{-\widetilde{\alpha}} K^{\widetilde{\beta}} \leq 1 \\
& \delta N \tilde{A}^{-1} P^{\widetilde{\alpha}} N^{-\widetilde{\beta}} \leq 1 \\
& \tilde{c} P^{-1} \leq 1 \\
& {[(1+\mu) \bar{P}]^{-1} P \leq 1} \\
& (\mu, \alpha, \beta, \delta) \in \mathbb{R} ;\left(c^{m}, A^{m}, G^{m}, P, K, N, \bar{P}, F C\right) \in \mathbb{R}^{+}
\end{aligned}
$$

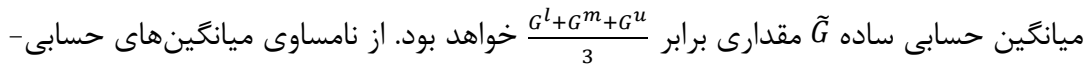
هندسى' در مورد رابطه ميانگين حسابى و هندسى مى دانيم كه ميانگين حسابى حداقل برابر ميانگين

$\frac{G^{l}+G^{m}+G^{u}}{3} \geq\left(G^{l} \cdot G^{m} \cdot G^{u}\right)^{1 / 3}$

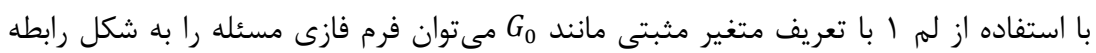

$$
G_{0} \equiv \operatorname{Min} G_{0}^{-1} \operatorname{Max}
$$

St:

$$
\sqrt[3]{G^{l} \cdot G^{m} \cdot G^{u}} \geq G_{0}
$$

$$
\begin{aligned}
& \quad G^{l} A^{l^{-1}} P^{\alpha^{u}-1} K^{-\beta^{l}}+c^{l} N G^{l} A^{l^{-1}} P^{\alpha^{u}-1} K^{-\beta^{l}} \leq 1 \\
& G^{m} A^{m-1} P^{\alpha^{m}-1} K^{-\beta^{m}}+c^{m} N G^{m} A^{m-1} P^{\alpha^{m}-1} K^{-\beta^{m}} \leq 1 \\
& G^{u} A^{u-1} P^{\alpha^{l}-1} K^{-\beta^{u}}+c^{u} N G^{u} A^{u-1} P^{\alpha^{l}-1} K^{-\beta^{u}} \leq 1 \\
& N^{-1} A^{l} P^{-\alpha^{u}} K^{\beta^{l}} \leq 1 \\
& \delta N A^{l^{-1}} P^{\alpha^{u}} K^{-\beta^{l} \leq 1} \\
& {[(1+\mu) \bar{P}]^{-1} P \leq 1} \\
& c^{l} P^{-1} \leq 1 \\
& (\mu, \alpha, \beta, \delta) \in \mathbb{R} ; \quad\left(c^{m}, A^{m}, G^{m}, P, K, N, \bar{P}, F C\right) \in \mathbb{R}^{+}
\end{aligned}
$$


نامساوى اولين محدوديت مسئله با تقسيم دوطرف بر

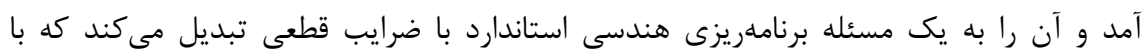

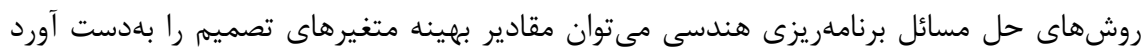
.(Kamaei et al., 2019; Rahmaniani et al., 2012; Islam \& Mandal, 2019)

\section{تخمين ضرايب و حل مدل}

براى تعيين قيمت بهينه خدمات IXP ايران در جار جوب مدلهاى برنامهريزى (• (T) و (T (T) نياز به تخمين كششهاى قيمتى تقاضا و هزينه نهايى IXP داريهم. براى تخمين آنها ابتدا توابع تقاضا و دورين

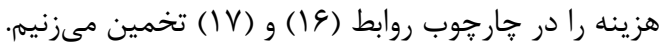
تخمين ضرايب تابع تقاضا: اطلاعات و دادههاى مربوط به فعاليت اين مراكز با توجه به نوريا نوريا

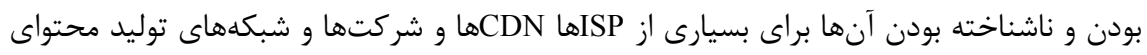

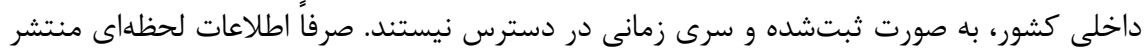

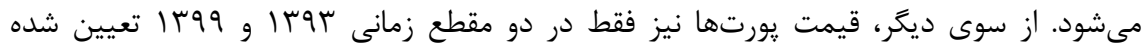
و تغيير كرده است كه حتى در صورت وجود اطلاعات مربوط به تعداد مشتركان در سال سوهبا، دادههاى اين دو سال نمىتواند مبناى تخمين دقيقى از ضرايب تقاضا باشد. بنابراين، براى تخمين

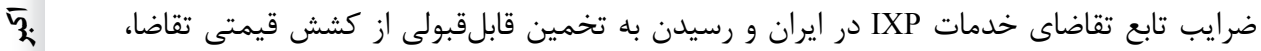
از آخرين دادههاى منتشرشده توسط آهاى بينالمللى با ساختار ارائه خدمات مشابه با ايران كه

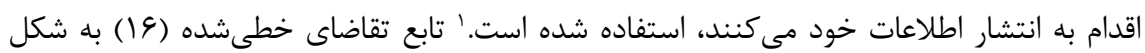
براى هر يورت تعريف شده است كه در آن ASi $\ln \left(A S_{i}\right)=c+\alpha \ln \left(P_{i}\right)+\beta K_{i}$ خودكردان متصل به نقطه تبادل ترافيك i-ام، Pi متوسط قيمت ماهانه يورت به ميليون ريال، و تعداد خدمات IXP i است. با توجه به اين كه در مدلهاى تقاضا، قيمت بهطور معمول درون درونزاست، آزمون درونزايى با استفاده از اختلاف آماره J در دو حالت مقيد و نامقيد آنجام شده است است. مقدار

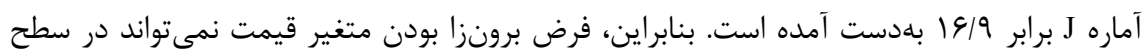

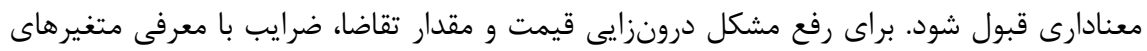
ابزارى به روش 2SLS تخمين زده شدهاند. متغير لكاريتم n (مجموع تمام يورتهاى IXP) به عنوان

و Www.linx.net به صورت مستقيم از سايت آنها اخذ شده است. سايتهاى IXP دادهاى هرای

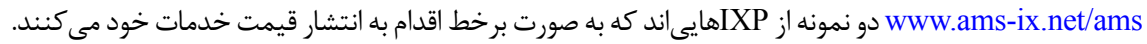


متغيرهاى ابزارى استفاده شده است. براى اينكه متغير ابزارى مناسبى انتخاب شود، بايد دو شرط

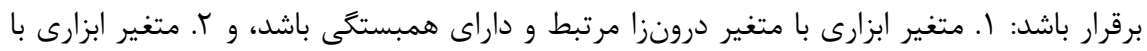

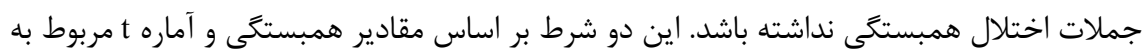
معنادارى آنها در ادامه بررسى شدهاند كه بر اساس آماره t هر دو شرط قابليذيرش هستند.

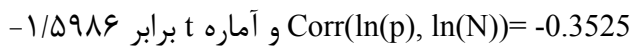

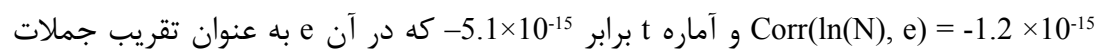

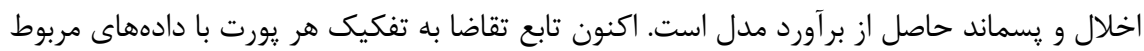
به قيمت و تعداد ASهاى متصل به هر يك بر اساس آخرين اطلاعات مندرج در سايتهاى • ب مركز

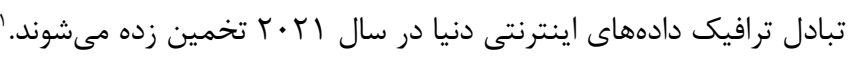

جدول rا: برآورد ضرايب تابع تقاضا براى بورت

\begin{tabular}{|c|c|c|c|c|}
\hline p-value & آماره & انحراف معيار & ضريب بر آوردشده & متغير \\
\hline$\cdot / \cdot Y \wedge \Delta$ & T/FFIA & $r / \cdot F \cdot 1$ & $4 / 9111$ & ثابت \\
\hline$\cdot l \cdot v \cdot f$ & $-1 / 90 \wedge f$ & - MFAIR & 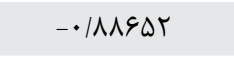 & $\log (\mathrm{P})$ \\
\hline - ITHFT & I/TFMI & 1/र9५9 & I/GIKT & $\log (\mathrm{K})$ \\
\hline \multicolumn{4}{|c|}{$\cdot / 1 \wedge \vee V$} & $\mathrm{R} 2$ \\
\hline & $\cdot / \cdot V \cdot r$ & p-value & $\Delta / T \cdot \Lambda F$ & BPG test: $\mathrm{n} \times \mathrm{R} 2$ \\
\hline
\end{tabular}

جدول זّ: برآورد ضرايب تابع تقاضا براى يورت 10GE

\begin{tabular}{|c|c|c|c|c|}
\hline p-value & t & انحراف معيار & ضريب بر آوردشده & متغير \\
\hline$\cdot / \cdot v$ & $r / / \Delta \Delta \Delta$ & $r / \cdot 119$ & $9 / \Delta \cdot r T$ & ثابت \\
\hline$\cdot \cdot \cdot v r$ & $-1 / 9 \Delta \Lambda f$ & . FAIV & $-1 / 91 Y \Delta$ & $\log (\mathrm{P})$ \\
\hline$\cdot / \cdot 1 r V$ & l/AIET & $1 / \cdot \Delta \wedge r$ & $r / 9 \Lambda \cdot r$ & $\log (\mathrm{K})$ \\
\hline \multicolumn{4}{|c|}{. IFrGA } & $\mathrm{R} 2$ \\
\hline & . / YAN & p-value & r/AIVG & BPG test: $n \times R 2$ \\
\hline
\end{tabular}

ا. اين اطلاعات به صورت جداءانه و از طريق سايت نقاط تبادل ترافيك اينترنت جمعآورى شده است (جدول 
جدول †ُ بر آورد ضرايب تابع تقاضا براى بورت 100GE

\begin{tabular}{|c|c|c|c|c|}
\hline p-value & آماره t & انحراف معيار & ضريب بر آوردشده & متغير \\
\hline ./1r99 & $r / 99 \cdot \Delta$ & $F / \cdot V r \Delta$ & G/TVFA & ثابت \\
\hline$\cdot / \cdot \vee 91$ & $-1 / \wedge \wedge \wedge \vee$ & - IAVET & $-1 / \cdot r 9 \Lambda$ & $\log (\mathrm{P})$ \\
\hline $.1 \cdot 1 V 9$ & I/DEFA & - IDFAT & T/MATT & $\log (\mathrm{K})$ \\
\hline \multicolumn{4}{|c|}{ • $/ T \backslash \Delta T$} & $\mathrm{R} 2$ \\
\hline &.$/ r q f F$ & p-value & T/FFAQ & BPG test: $n * R 2$ \\
\hline
\end{tabular}

علاوه بر آزمون ناهمسانى واريانس كه به روش بروش-ياگان-كادفرى' انجام شده و نتايج آن در

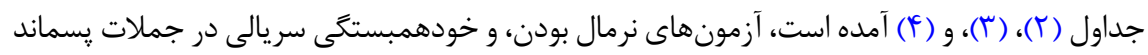
نيز براى تمام مدل هاى فوق انجام شد كه نتايج آن حاكى از قابل اعتماد بودن ضرايب برآ آوردشده است.

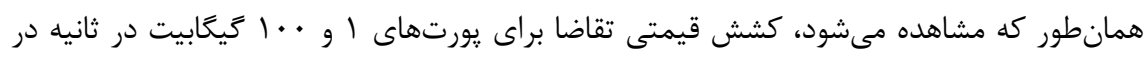

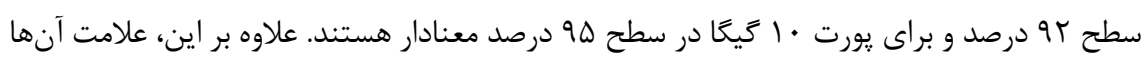
مطابق انتظار است. IXP تخمين هزينه واحد يورت: مركز تبادل ترافيك انقلاب تهران در حال حاضر يركارترين

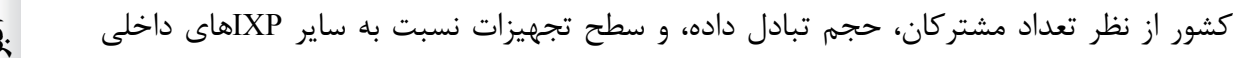

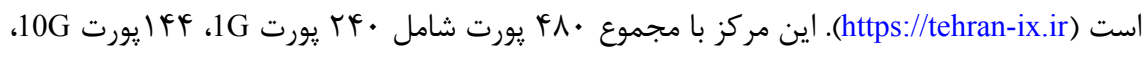

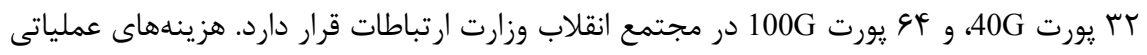

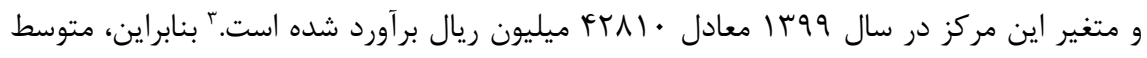

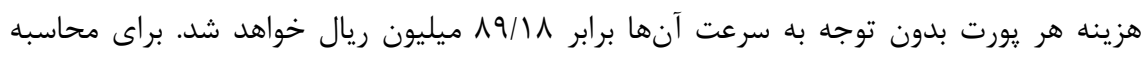

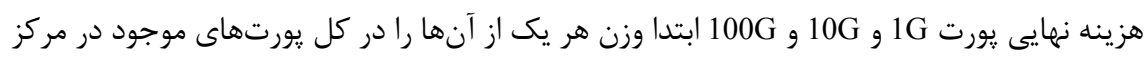
محاسبه، سيس در متوسط هزينه هر يورت ضرب مى كنيه. به اين ترتيب، هزينه نهايى يورت

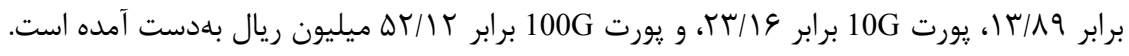

\section{Breusch-Pagan-Godfrey}

2. https://tehran-ix.ir

r. هزينهاى خريد و نصب و راهاندازى تجهيزات به عنوان هزينهاى ثابت و سرمايهاى و همجنين، هزينه 
IXP Y. متوسط قيمت جهانى واكذارى يورتهاى IXP: متوسط قيمت جهانى يورتهاى

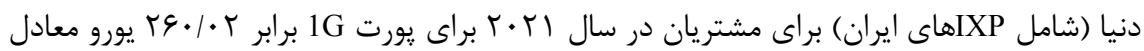

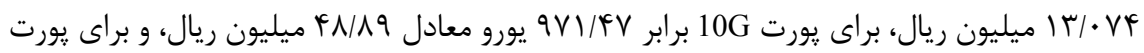

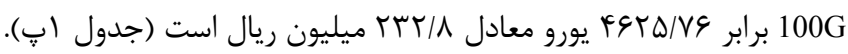

\section{جواب مدل با ضر ايب قطعى}

با توجه به نتايج تخمين سه مدل تقاضاى خدمات IXP و اطلاعات مربوط به هزينه و قيمت

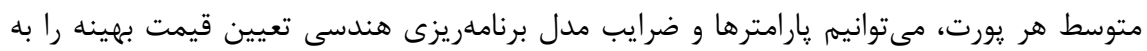
صورت جدول (ه) خلاصه كنيم:

جدول ه: ضرايب و بارامترهاى تخمينى براى الكوى برنامهريزى هندسى قطعى

\begin{tabular}{|c|c|c|c|c|c|c|c|}
\hline C & $\mu$ & & $\mathbf{N}$ & $\mathbf{A}$ & $\boldsymbol{\beta}$ & $\alpha$ & نوع «ورت \\
\hline $1 \pi / 19$ & .11 & $\mid r / \cdot V$ & $r \Delta \mu$ & IFD/GT & I/GITT & - /AQDY & $1 \mathrm{GE}$ \\
\hline$r r / l s$ & $\cdot / 1$ & FN/A9 & 190 & $1 \mathrm{rr \Delta q/V}$ & $r / 9 \Lambda \cdot r$ & I/9ITD & $10 \mathrm{GE}$ \\
\hline$\Delta T / I T$ & $\cdot / 1$ & TrtA & $g f$ & $\Delta \wedge \varepsilon / 89$ & T/KATY & $1 / . r 91$ & $100 \mathrm{GE}$ \\
\hline
\end{tabular}

با در نظر كرفتن ضرايب فوق و جايخذارى در مدل (1))، قيمت بهينه خدمات IXP در حالت

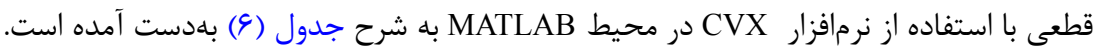

\begin{tabular}{|c|c|c|c|}
\hline بيشينه سود & قيمت بهينه & قيمت فعلى & نوع پيورت \\
\hline$r \Delta q / q$ & $I F / T V$ & 1. & $1 \mathrm{GE}$ \\
\hline$\Delta \cdot \Delta r / I$ & $\Delta r / V V$ & $r$. & $10 \mathrm{GE}$ \\
\hline$M \cdot \Delta r$ & TDS & $r \Delta$. & $100 \mathrm{GE}$ \\
\hline
\end{tabular}

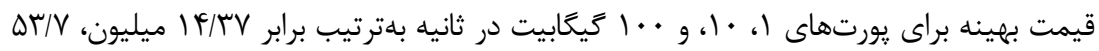

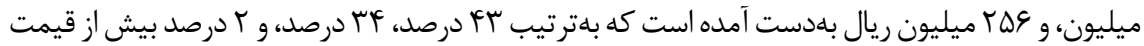

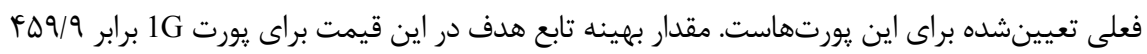


ميليون، براى يورت 10G برابر ه • D ميليون، و براى يورت 100G برابر سه • Iا ميليون ريال است. مجموع

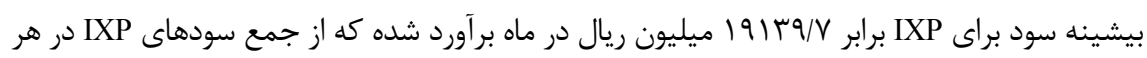

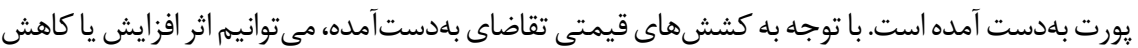
قيمت را بر مقدار تقاضا ارزيابى كنيه. براى يورتهاى آَيحابيت، هر يك درصد افزايش در قيمت، بافرض

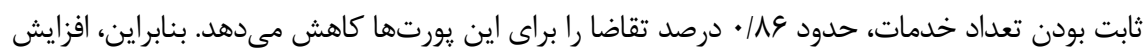

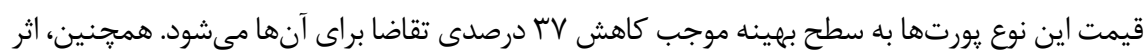

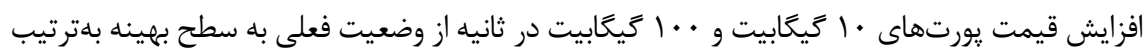

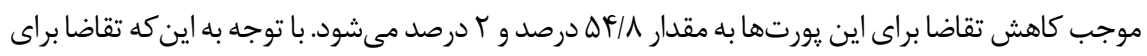

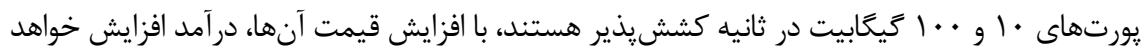
يافت. اما افزايش قيمت يورتهاى ا كيكابيت موجب كاهش در آمد خواهد شد.

\section{جواب مدل با ضرايب فازى}

براى يافتن پاسخهاى بهينه در الكوى برنامهريزى هندسى فازى (YT)، بر اساس ضرايب

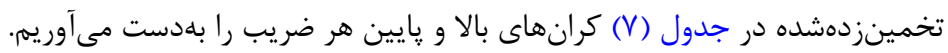

جدول Y: كرانهاى بالا و پإيين ضرايب مورد استفاده در مدل Fuzzy GP براى يورتهاى مختلف

\begin{tabular}{|c|c|c|c|c|}
\hline كران هايين (x) & نقطه مركزى (x) & كران بالا & نوع يورت & \\
\hline $.194 \wedge 9$ & - / $A 9 \Delta T$ & $1 / \cdot 110$ & $1 \mathrm{GE}$ & \multirow{3}{*}{$\alpha$} \\
\hline $1 / r \cdot 9 r$ & $1 / 91 T \Delta$ & $T / \cdot 10$ & $10 \mathrm{GE}$ & \\
\hline . IVYTK & $1 / . r 91$ & I/TAVT & $100 \mathrm{GE}$ & \\
\hline $1 / 4 \cdot 91$ & I/GITY & $T / \cdot I \Delta T$ & $1 \mathrm{GE}$ & \multirow{3}{*}{$\beta$} \\
\hline T/KTLT & $r / 9 \Lambda \cdot r$ & r/VTAK & $10 \mathrm{GE}$ & \\
\hline IVGFI & T/TOTT & $r / q Y \cdot r$ & $100 \mathrm{GE}$ & \\
\hline $1.9 / r$ & $\mid F Q / G T$ & $\mid A T / \cdot T$ & $1 \mathrm{GE}$ & \multirow{3}{*}{ A } \\
\hline $1 . .19 / \mathrm{V}$ & $1 r r \Delta q / v$ & $19999 / 9$ & 10GE & \\
\hline$f q . / \cdot 1$ & $\Delta \wedge \& / 99$ & Gr/Tr & $100 \mathrm{GE}$ & \\
\hline $1 / 79$ & $1 \pi / 19$ & $1 \% N / 9$ & $1 \mathrm{GE}$ & \multirow{3}{*}{$\mathrm{C}$} \\
\hline$r / \mu$ & rm/le & (T)/ & $10 \mathrm{GE}$ & \\
\hline$\Delta / T_{1}$ & $\Delta T / I T$ & $\Delta T I / T$ & 100GE & \\
\hline
\end{tabular}


مدل را با دادههاى فوق و با استفاده از نرمافزار 'GPPLAB حل كردهايم كه نتايج آن به صورت

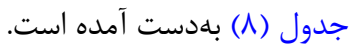

\begin{tabular}{|c|c|c|c|}
\hline بيشينه سود & قيمت بهينه & قيمت فعلى & نوع يورت \\
\hline$T V I F / F$ & $11 / \cdot r$ & 1. & $1 \mathrm{GE}$ \\
\hline FTEEIT & $r q / r$ & f. & $10 \mathrm{GE}$ \\
\hline ITIGF & r/T/G & $r \Delta$. & $100 \mathrm{GE}$ \\
\hline
\end{tabular}

همانطور كه در جدول (^) نشان داده شده است، با بكاركيرى و استفاده از ضرايب با پارامترهاى فازى به شرح جدول (V)، مدل براى تمام يورتها داراى جواب شدنى بهينه است. متوسط قيمت

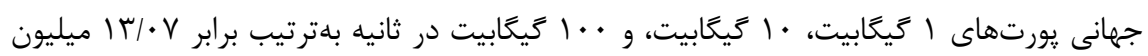

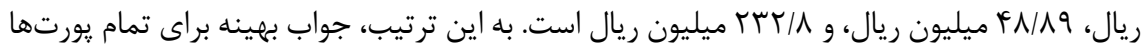

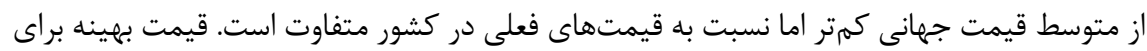
يورتهاى 1GE حدود س/ • ا درصد بيشتر از قيمت فعلى و قيمت بهينه يورتهاى 10GE و 100GE

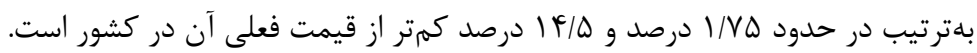

\section{ارزيابى قيمتهاى بهينه بر سود IXP}

در بخش قبل، قيمتهاى بجينه را بر اساس دو مدل قطعى و فازى تخمين زديم. اكنون مىخواهيم

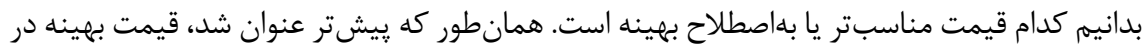
اين يروهش قيمتى است كه سود IXP را بيشينه كند. براى ارزيابى سود IXP بر اساس يافتههاى فوق،

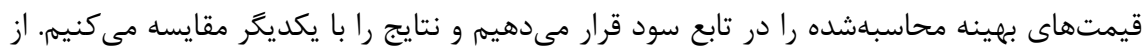
آنجايى كه در مسئله برنامهريزى هندسى، براى هر يورت يك برنامه در نظركرفته و مدل حل شده

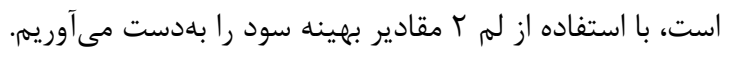

لم ז': براى توابع حقيقى كه روى تمام مقادير دامنه خود يِيوسته باشند، همارزى زير برقرار است: $\operatorname{Max}\left\{\sum_{i=1}^{n} f_{i}\left(x_{i}\right)\right\} \equiv \sum_{i=1}^{n}\left\{\operatorname{Max} f_{i}\left(x_{i}\right)\right\}$ 
به عبارت ديكر، بيشينه مجموع توابع مستقل از يكديكر با مجموع بيشينه تكتك توابع برابر است.

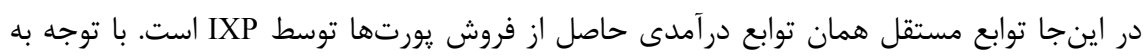
اين كه تابع هزينه نيز به صورت خطى تعريف شده است، بنابراين خواهيم داشت:

جدول 9: مقايسه مقادير بيشينه سود

\begin{tabular}{|c|c|}
\hline مقدار بيشينه سود (ميليون ريال/ ماه) & مدل تعيين قيت بهينه \\
\hline $1 \wedge \Delta \& \Delta$ & برناملريزى هندسى با ضرايب قطعى \\
\hline $191 Y F$ & برنامدريزى هندسى با ضرايب فازى \\
\hline
\end{tabular}

可.

همانطور كه در جدول (9) نشان داده شده است، علىرغم اينكه قيمتهاى بهينه مدل برنامهريزى هندسى با ضرايب قطعى، بيشتر از قيمتهاى بهينه مدل برنامهريزى هندسى با فيا

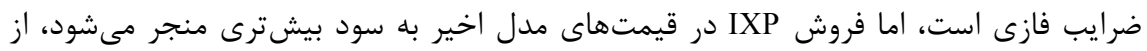

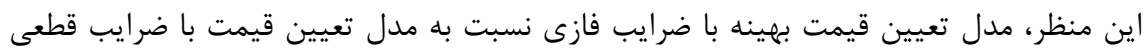
برترى دارد.

با توجه به اينكه مدل برنامهريزى هندسى فازى سود بيشتر با قيمتهاى كمترى نتيجه داده

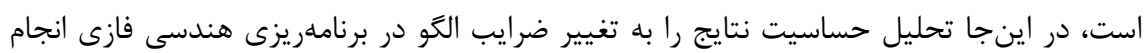
مى دهيم. براى اين كار كشش تخمينزدهشده را در فاصله • 9- تا • 9+ درصد تغيير داده و نتايج آن

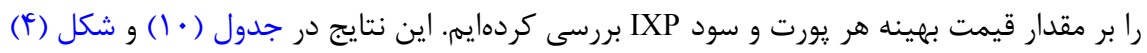
نشان داده شده است. براى يورتهاى 1GE و 100GE، مدل در فاصله تغييرات مورد اشاره، داراى

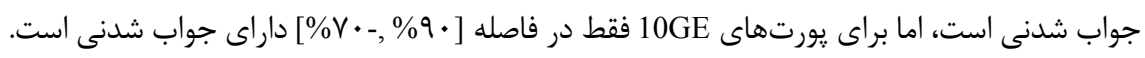
در جدول (• ()، مقايسه نتايح مربوط به قيمت و سود بهينه براى تغيير ضرايب در اين فاصله محاسبه 
جدول • 1: تحليل حساسيت سود و قيمت بهينه يورت 1GE نسبت به تغيير كشش قيمتى تقاضا

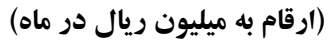

\begin{tabular}{|c|c|c|c|c|}
\hline بيشينه سود & قيمت بهينه يورت & قيمت بهينه يورت & قيمت بهينه & تغيير ضريب كشش (درصد) \\
\hline $191 \mathrm{TH}$ & $r \mid r / \cdot q r$ & Infeasible & IITrF & -9 . \\
\hline $191 \mathrm{rF}$ & rIT/qrr & Infeasible & II/TFF & $-V \cdot$ \\
\hline $191 \mathrm{KF}$ & rIr/vqA & FQ/qTT & $11 / 1 \mathrm{~V}$ & $-\Delta$. \\
\hline $191 \mathrm{KF}$ & $r / r / V \cdot r$ & $F T / / A V$ & $11 / 11$. & $-r$. \\
\hline $191 T F$ & IIT/GT & $f \cdot / \cdot \Delta V$ & $11 / \cdot \Delta \Delta$ & -1 \\
\hline $191 \mathrm{KF}$ & • & гq/r.. & $11 / \cdot r$. & . \\
\hline $191 \mathrm{KF}$ & TIT/DVT & ए人/૬૬| & $11 / \cdot 9$ & 1 \\
\hline $191 \mathrm{KF}$ & rIT/DT & rV/GیI & 1.1994 & r. \\
\hline $191 \mathrm{TF}$ & rIT/KAT & एद/q૬l & $1.194 \mathrm{~V}$ & $\Delta \cdot$ \\
\hline 19174 & TIT/KFA & سוf & $1 \cdot 1194$ & $V \cdot$ \\
\hline $191 \mathrm{TF}$ & $r \mid r / \Delta 9 \Lambda$ & rه/9人 & $1 \cdot 1 \wedge 90$ & 9 . \\
\hline
\end{tabular}


ثر كاهش ضريب كشش قيمتى تقاضا بر قيمت بهينه يورت IGE

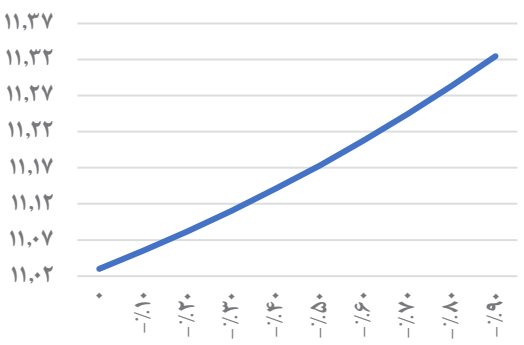

اثر افزايش ضريب كشش قيمتى تقاضا بر قيمت بهينه بيورت 1GE

$11,+\Delta$

$11, *+$

$1+, 9 \Delta$

$1 \cdot, 9 \cdot$

$1 \cdot, \wedge \Delta$

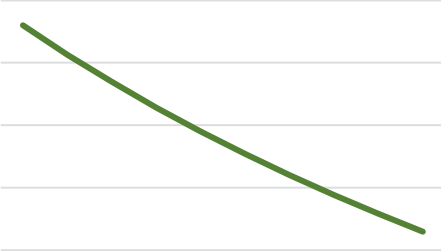

广. 广 广. 广
اثر افزايش ضريب كشش قيمتى تقاضا بر قيمت بهينه يورت 10GE

اثر كاهش ضريب كشش قيمتى تقاضا بر قيمت بهينه يورت 10GE

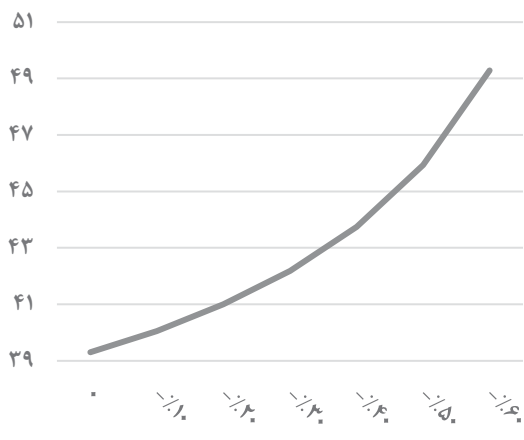

DI

rq,

rq, r

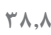

r^,r

$r v, \Lambda$

$r v, r$

$r q, \Lambda$

re,r

$r \Delta, \wedge$

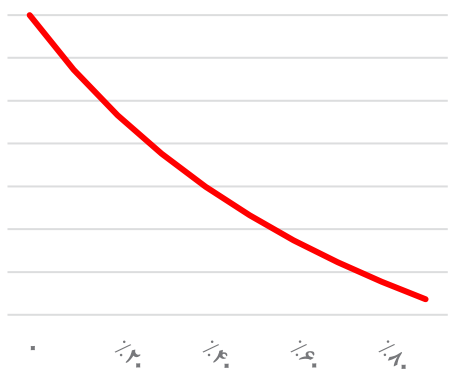

100GE اثر افزايش ضريب كشش تقاضا بر قيمت بهينه يورتهاى

rIT,\$D

rir,s.

$r \mid \mathrm{r}, \Delta$

מוT.

TIT,FD

rir,f.

rIT, ra

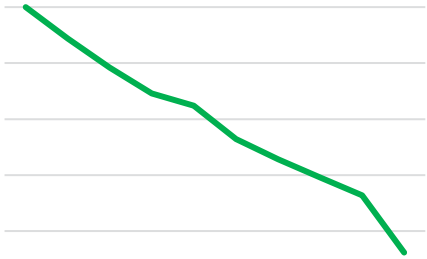

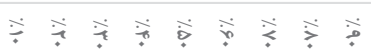

اثر كاهش ضريب كشش تقاضا بر قيمت بهينه بورتهاى 100GE

rIF,

rIf,

rif,

rir,q

rir,

rir,

rir,g

TIT, A

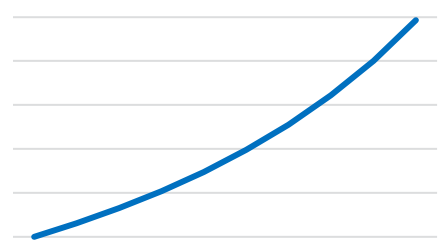

\% \% \% \% 


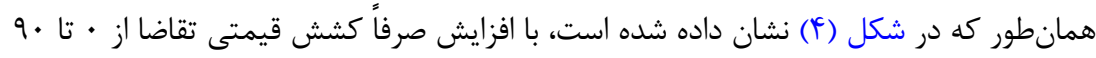
10GE درصد، قيمت بهينه يورتها كاهش مىيابند. بيشترين تاثير مربوط به قيمت بهينه يورتهات

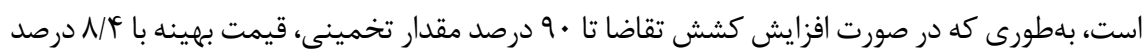

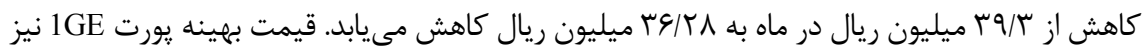

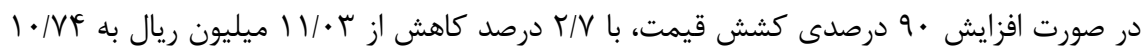

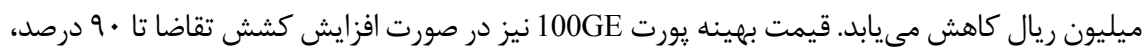

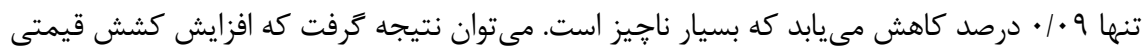
تقاضا براى يورتهاى 100GE اثرى بر قيمت بهينه مدل ندارد. از سوى ديخر، كاهش كشش قيمتى

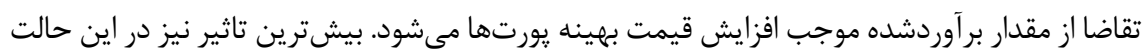

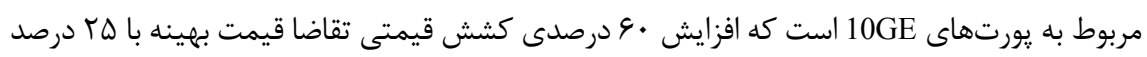

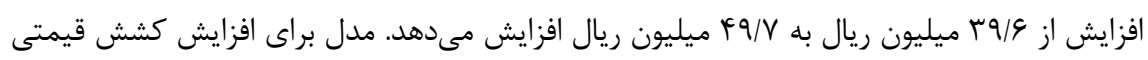
تقاضا بيشتر از • ع درصد فاقد جواب شدنى است. براى يورتهاى 1GE و

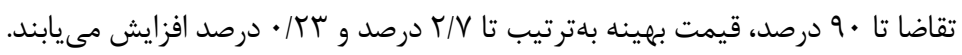

\section{بحث و نتيجه}

اين يروهش با هدف تعيين قيمت بهينه خدمات مراكز تبادل ترافيك اينترنت كشور كه يكى از زيرساختهاى فيزيكى مههم در ساختار ارتباطات است، انجام شده است. خدماتى كه در اين مراكز

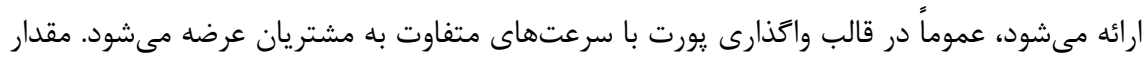

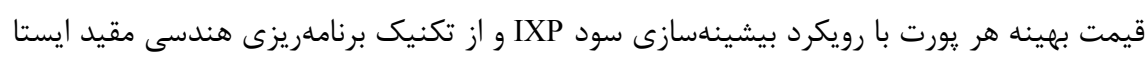
با ضرايب فازى محاسبه و با قيمتهاى ابلاغى مقايسه شده است.

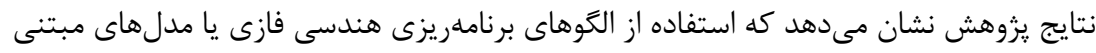

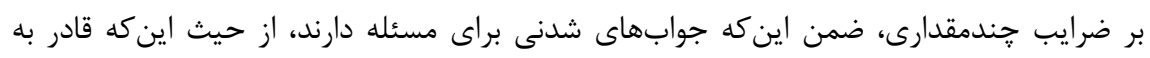

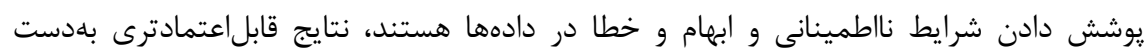
مى دهند. بهطور كلى، بر اساس بررسىها و نتايج اين يزوهش مى توتوان كَت تقاضا براى خدمات مراكز

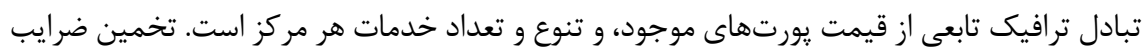

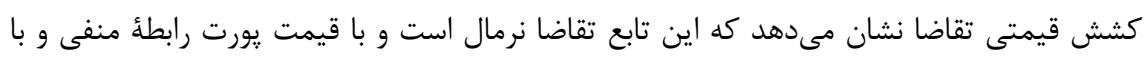
تعداد خدمات رابطه مستقيم و مثبت دارد. 
بر اساس نتايج حاصل از حل مدل برنامهريزى هندسى فازى، قيمت بهينه براى يورتهاى 1 إن

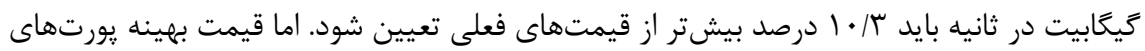
10GE برابر س/ ب/ ميليون ريال در ماه محاسبه شده است كه I درصد از مقدار ابلاغى فعلى كمتر

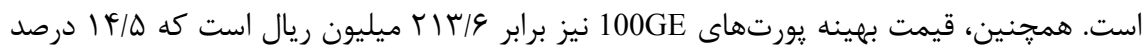
كمتر از قيمتهاى ابلاغى فعلى است.

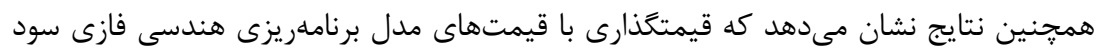
بيشترى را در مقايسه با قيمتهاى مدل برنامهريزى هندسى قطعى نتيجه مي دهد. در مدل با ضرايب

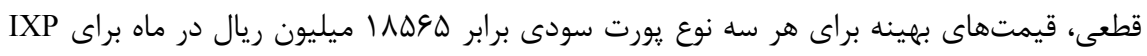

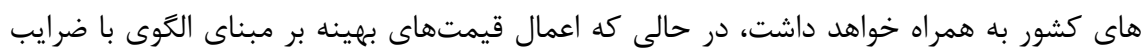

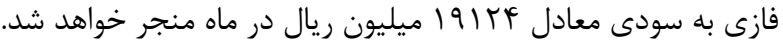

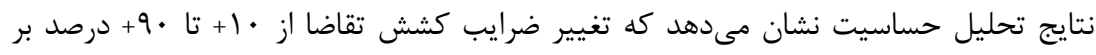

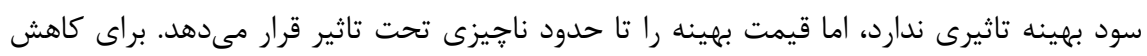

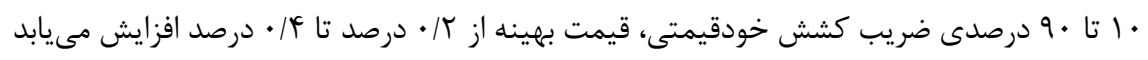

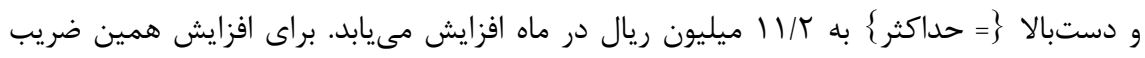

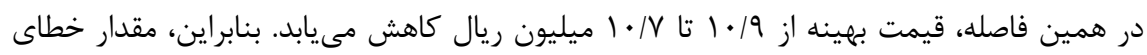
محاسباتى در تخمين ضريب كشث قيمتى تاثير معنادارى بر قيمت بهينه ندارد.

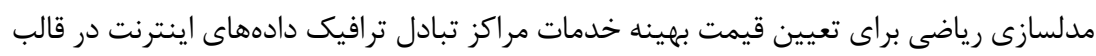

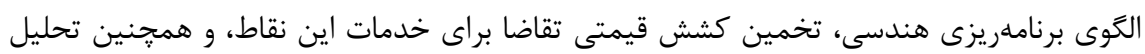

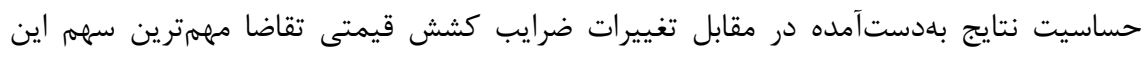
يزوهش در ادبيات است. در اين راه مههمترين محدوديت و مشكل براى انجام اين يزوهش و و احتمالاً

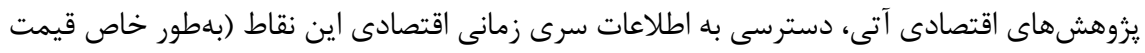

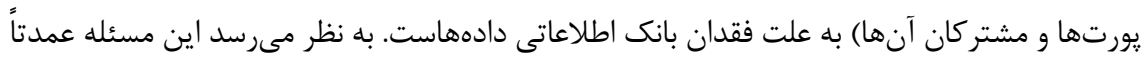

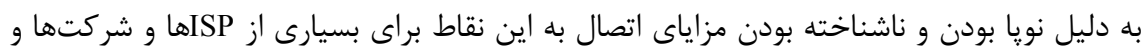

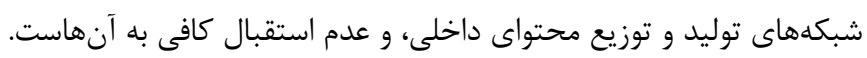

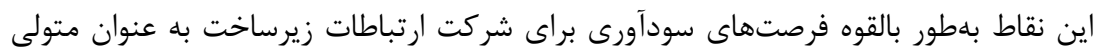
اصلى ايجاد و راهاندازى اين نقاط و كارايى و كيفيت بالاتر در ارسال و دريافت دادهها براى ساير بردي

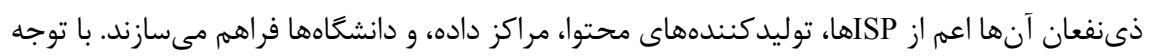


به اهميت روزافزون ارتباطات و اينترنت، و تاثيرات عميقى كه توسعه فعاليتهاى مبتنى بر آن بر جنبههاى مختلف اقتصادى، اعم از سطوح خرد و كلان بر جاى مى گذارد، لازم است توجه بيشترى به مبانى و روشهاى قيمتخذارى اين خدمات به عمل آيد. بر اساس اين، ييشنهاد مىشود كميسيون

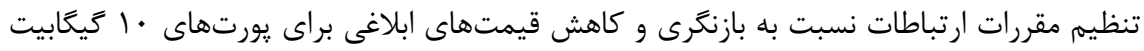

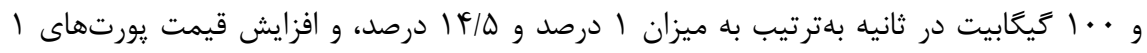
كيكابيت در ثانيه به ميزان س/ • ا درصد نسبت به قيمتهاى ابلاغى فعلى اقدام نمايد. همجنين، مراكز

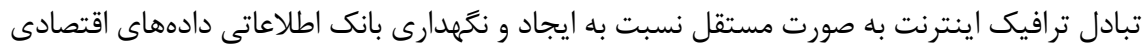

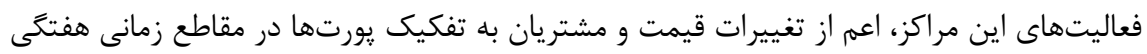

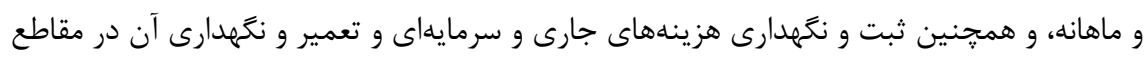
زمانى ماهانه و يكساله اقدام نمايند. در يايان، استفاده از نظريه بازىها براى فرموله كردن و نحوه

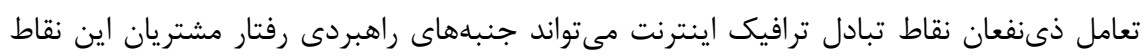

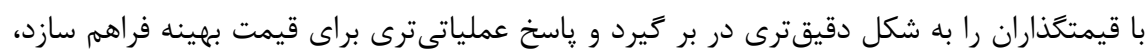

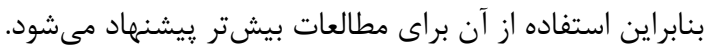

اظهاريه

نويسنده از مساعدت و كمكهاى معنوى محسن سياسى در گروه ارتباطات ثابت يزوهشخاه

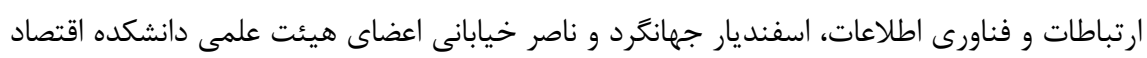
دانشگاه علامه طباطبايى، از ييشنهادها و نكات اصلاحى و ارزنده داوران محترم ناشناس، و ويراستار

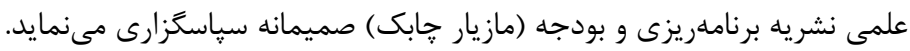

Accongiagioco, G., Altman, E., Gregori, E., \& Lenzini, L. (2014). A Game Theoretical Study of Peering vs Transit in the Internet. Paper Presented at the 2014 IEEE Conference on Computer Communications Workshops (INFOCOM WKSHPS). https://doi.org/10.1109/INFCOMW.2014.6849330

Bagheri, A., \& Nazeman, H. (2020). Investigating Competition in Iran's Electricity Industry. The Journal of Planning and Budgeting, 25(1), 87-108. http://jpbud.ir/article-1-46-fa.html 
Böttger, T., Antichi, G., Fernandes, E. L., di Lallo, R., Bruyere, M., Uhlig, S.,... Castro, I. (2018). Shaping the Internet: 10 Years of IXP Growth. arXiv preprint arXiv:1810.10963.

Boyd, S., Kim, S.-J., Vandenberghe, L., \& Hassibi, A. (2007). A Tutorial on Geometric Programming. Optimization and Engineering, 8(1), 67-127. https://doi.org/10.1007/s11081-007-9001-7

Chen, C.-K. (2000). Optimal Determination of Quality Level, Selling Quantity and Purchasing Price for Intermediate Firms. Production Planning \& Control, 11(7), 706-712. https://doi.org/10.1080/095372800432179

Courcoubetis, C., \& Weber, R. (2003). Pricing Communication Networks: Economics, Technology and Modelling: John Wiley \& Sons.

Duffin, R., \& Peterson, E. L. (1966). Duality Theory for Geometric Programming. SIAM Journal on Applied Mathematics, 14(6), 1307-1349. https://doi.org/10.1137/0114105

Ecker, J. G. (1980). Geometric Programming: Methods, Computations and Applications. SIAM Review, 22(3), 338-362. https://doi.org/10.1137/1022058

Ha, S., Sen, S., Joe-Wong, C., Im, Y., \& Chiang, M. (2012). TUBE: Time-Dependent Pricing for Mobile Data. Paper Presented at the Proceedings of the ACM SIGCOMM 2012 Conference on Applications, Technologies, Architectures, and Protocols for Computer Communication.

Hande, P., Chiang, M., Calderbank, R., \& Zhang, J. (2010). Pricing Under Constraints in Access Networks: Revenue Maximization and Congestion Management. Paper Presented at the 2010 Proceedings IEEE INFOCOM.

He, H., Xu, K., \& Liu, Y. (2012). Internet Resource Pricing Models, Mechanisms, and Methods. Networking Science, 1(1-4), 48-66. https://doi.org/10.1007/s13119-011-0004-5

Islam, S., \& Mandal, W. A. (2019). Fuzzy Geometric Programming Techniques and Applications: Springer.

Kamaei, S., Kamaei, S., \& Saraj, M. (2019). Solving a Posynomial Geometric Programming Problem with Fully Fuzzy Approach. Yugoslav Journal of Operations Research, 29(2), 203-220. https://doi.org/10.2298/YJOR1811

Kelly, F. P., Maulloo, A. K., \& Tan, D. K. H. (1998). Rate Control for Communication Networks: Shadow Prices, Proportional Fairness and Stability. Journal of the Operational Research Society, 49(3),237-252.https://doi.org/10.1057/palgrave.jors.2600523

Kim, D., \& Lee, W. J. (1998). Optimal Joint Pricing and Lot Sizing with Fixed and Variable Capacity. European Journal of Operational Research, 109(1), 212-227. https://doi.org/10.1016/S0377-2217(97)00100-8

MacKie-Mason, J., \& Varian, H. (1995). Public Access to the Internet: MIT Press, Chapter Pricing the Internet.

Mazumdar, R., Mason, L. G., \& Douligeris, C. (1991). Fairness in Network Optimal Flow Control: Optimality of Product Forms. IEEE Transactions on Communications, 39(5), 775-782.

Muttitanon, W., \& Samanchuen, T. (2020). Internet Cost Reduction Using Internet Exchange Point: A Case Study of Internet Network of Thailand. Wireless Personal Communications, 115(1), 3177-3198. https://doi.org/10.1007/s11277-020-07198-1

Ojha, A. K., \& Biswal, K. (2010). Posynomial Geometric Programming Problems with Multiple Parameters. Journal of Computing, 2(1), 84-90. 
Rahmaniani, R., Sadjadi, S. J., Shafia, M. A., \& Rahmaniyan, N. (2012). The Optimal Pricing Model in an Uncertain and Competitive Environment: Using Possibilitic Geometric Programming Approach. African Journal of Business Management, 6(46), 11565-11574. https://doi.org/10.5897/AJBM12.704

Rao, S. S. (2019). Engineering Optimization: Theory and Practice: John Wiley \& Sons.

Sadjadi, S., Yousefli, A., \& Ghezelsoflou, R. (2011). Optimal Pricing for Internet Service Providers: Fuzzy Geometric Programming Model. African Journal of Business Management, 5(17), 7291-7295. https://doi.org/10.5897/AJBM10.1122

Sato, K., \& Nakashima, K. (2020). Optimal Pricing Problem for a Pay-Per-Use System Based on the Internet of Things with Intertemporal Demand. International Journal of Production Economics, 221(1), 107477. https://doi.org/10.1016/j.ijpe.2019.08.012

Sen, S., Joe-Wong, C., Ha, S., \& Chiang, M. (2013). Smart Data Pricing (SDP): Economic Solutions to Network Congestion. Recent Advances in Networking, 1(1), 221-274.

Shakkottai, S., Srikant, R., Ozdaglar, A., \& Acemoglu, D. (2008). The Price of Simplicity. IEEE Journal on Selected Areas in Communications, 26(7), 1269-1276.

You, P.-S., Hsieh, Y.-C., \& Huang, C.-M. (2009). A Particle Swarm Optimization Based Algorithm to the Internet Subscription Problem. Expert Systems with Applications, 36(3), 7093-7098. https://doi.org/10.1016/j.eswa.2008.08.080

Zadeh, L. A. (1978). Fuzzy Sets as a Basis for a Theory of Possibility. Fuzzy Sets and Systems, 1(1), 3-28. https://doi.org/10.1016/0165-0114(78)90029-5

Zener, C. (1961). A Mathematical Aid in Optimizing Engineering Designs. Proceedings of the National Academy of Sciences of the United States of America, 47(4), 537-539.

Zhang, F. (2011). Pricing in Multi-Service Communication Networks: A Game-theoretic Approach. (Doctor of Philosophy). The University of Oklahoma,

$$
\begin{aligned}
& \text { ب) فارسى } \\
& \text { جهانكرد، اسفنديار (ع) (1). اقتصاد شبكهاى: مدل هاى قيمتخذارى محصولات شبكهاى. نشريه /قتصاد و تجارت }
\end{aligned}
$$

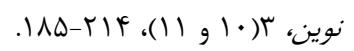

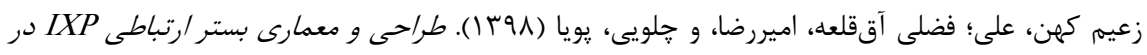

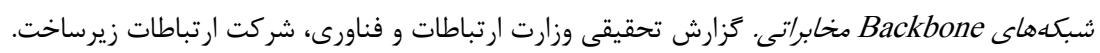

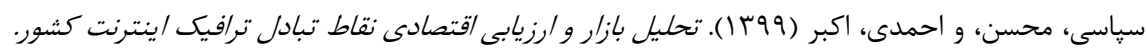

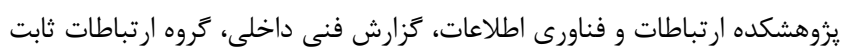

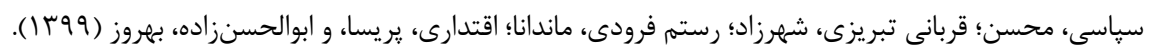

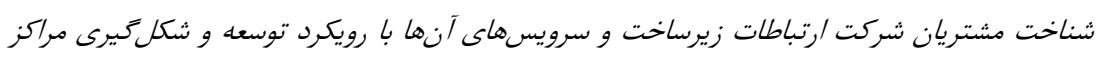

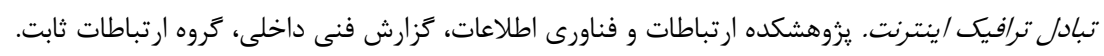


جدول ابֶ: قيمت «يورتهاى IXP 20 دنيا (به يورو)

\begin{tabular}{|c|c|c|c|c|}
\hline تعداد ASN & 100GE قيمت يورت & قيمت يورت 10GE & قيمت يورت 1GE & نام IXP \\
\hline 199 & (ع... & VT. & $r \Delta \cdot$ & ams-ix \\
\hline re & $11199 / 9$ & $14 \ldots$ & rᄉ. & bknix \\
\hline 11 & $r v \Delta \cdot$ & $V \Delta \cdot$ & $r \cdot$. & bcix \\
\hline pq & $\mid \Delta G 9 / \Lambda$ & भ१।/V & $v \cdot$ & bix \\
\hline fr & rq.. & $\varphi \Delta \cdot$ & $r \cdot$. & catnix \\
\hline 9) & $\Delta \cdots$ & $1 \ldots$ & $\Delta \cdots$ & ecix-ber \\
\hline 1 & מז... & 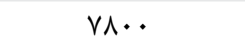 & 190 & espanix \\
\hline$r \cdot$ & $\vee \vee \Delta$ & 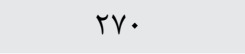 & $\wedge$. & gr-ix \\
\hline 199 & מוזי & $994 / 9$ & س מ & swissix \\
\hline 991 & $r y \cdot 1$ & $\Delta V Y / I$ & TFt & $\operatorname{lin} x$ \\
\hline Vr & $\Delta \cdot r q$ & $\Lambda \cdot \wedge$ & $r \cdot r$ & tehran-ix \\
\hline fr & rq.. & $\Delta \cdots$ & $r \cdot$ & catnix \\
\hline ITD & r/א & fFF & $r \Delta$ & sthix \\
\hline$\Delta$ & וזrr & VF. & $\mid \Delta \Lambda$ & notnodix \\
\hline זוץ & rMdr & $\Lambda \Gamma \wedge$ & $1 \cdots$ & hkix \\
\hline 199 & $\Delta \cdots$ & f.. & $1 \ldots$ & nix.cz \\
\hline TYD & rut. & FT. & rF. & dtel-ix \\
\hline$\Delta \varphi$ & FITd & sVD & TrA & bnix \\
\hline$\Lambda \Delta$ & 1199 & 109 & $i \wedge$ & qix.ca \\
\hline rr & $r \Delta \cdot$ & 191 & $1 \cdot r$ & rix \\
\hline
\end{tabular}

